\title{
The Very Idea of a First Amendment Right Against Compelled Subsidization
}

Gregory Klass

Georgetown University Law Center, gmk9@law.georgetown.edu

This work, copyright 2005 by Gregory Klass, was originally published in the UC Davis Law Review, vol. 38, pp. 1087-1139, copyright 2005 by The Regents of the University of California. All rights reserved. Reprinted with permission.

This paper can be downloaded free of charge from:

https://scholarship.law.georgetown.edu/facpub/124

38 U.C. Davis L. Rev. 1087-1139 (2005)

This open-access article is brought to you by the Georgetown Law Library. Posted with permission of the author. Follow this and additional works at: https://scholarship.law.georgetown.edu/facpub

Part of the Constitutional Law Commons, and the Law and Politics Commons 


\section{GEORGETOWN LAW Faculty Publications}

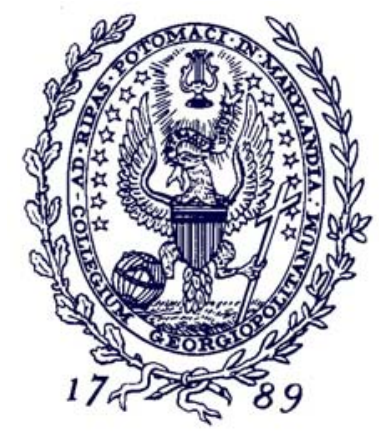

January 2010

\section{The Very Idea of a First Amendment Right Against Compelled Subsidization*}

38 U.C. Davis L. Rev. 1087-1139 (2005)

\section{Gregory Klass}

Professor of Law

Georgetown University Law Center gmk9@law.georgetown.edu

This paper can be downloaded without charge from:

Scholarly Commons: http://scholarship.law.georgetown.edu/facpub/124/

SSRN: http://ssrn.com/abstract $=587882$

Posted with permission of the author

*This work, copyright 2005 by Gregory Klass, was originally published in the UC Davis Law Review, vol. 38, pp. 1087-1139, copyright 2005 by The Regents of the University of California.

All rights reserved. Reprinted with permission. 


\title{
The Very Idea of a First Amendment Right Against Compelled Subsidization
}

\author{
Gregory Klass
}

\section{TABLE OF CONTENTS}

INTRODUCTION

I. PROBlems IN PRACTICE: Difficulties WiTH THE DOCTRINE AS IT

NOW STANDS

II. PROBLEMS IN THEORY: THE COURT'S FAILURE TO EXPLAIN THE

DOCTRINE

A. Does Compelled Subsidization Violate Dissenters' Freedom of

Belief?

B. Does Compelled Subsidization Interfere with Dissenters'

Freedom of Speech?

C. A First Amendment Harm to Individual Dissenters?

III. AN ALTERNATIVE ACCOUNT OF THE FIRST AMENDMENT RIGHT NOT TO SUBSIDIZE.

A. Old Holdings in New Theory

$B$. Applying and Extending the Approach

CONCLUSION: CAMPAIGN FINANCE REgULATION AGAIN 1138

- Assistant Solicitor General, Office of the New York State Attorney General. Law Clerk, Hon. Guido Calabresi, 2002-03; J.D., Yale Law School 2002; Ph.D., Graduate Faculty of the New School for Social Research 1999. I am grateful to Bruce Ackerman, Michelle Aronowitz, Guido Calabresi, Christopher Elmendorf, Owen Fiss, Caitlin Halligan, and Jed Handelman Shugerman for comments and conversations that have helped me develop the ideas in this Article. The views expressed in this Article do not represent those of the Office of the New York State Attorney General. 


\section{INTRODUCTION}

At least since the Supreme Court's 1976 landmark campaign finance decision in Buckley $v$. Valeo, the link between money and speech has been one of the battleground issues in First Amendment jurisprudence. Buckley's early critics honed in on this question, ${ }^{2}$ and it continues to provoke debate between justices. ${ }^{3}$ But as the campaign finance cases have progressed, and especially with the Court's recent decision in McConnell v. Federal Election Commission, ${ }^{4}$ which upheld almost all of the Bipartisan Campaign Reform Act of 2002, another equally fundamental issue has emerged: Is it permissible to restrict campaign contributions or independent advocacy not only to prevent corruption, but also, in the words of Justice Breyer, "to democratize the influence that money can bring to bear upon the electoral process" ${ }^{5}$ While the Buckley Court confidently declared that "the concept that government may restrict the speech of some elements of our society in order to enhance the relative voice of others is wholly foreign to the First Amendment, ${ }^{\prime 6}$ more recent decisions, including McConnell, have steadily chipped away at that categorical claim. ${ }^{7}$ And though a majority of the Court has yet to recognize a First Amendment interest in promoting equality of influence on or participation in electoral politics, there is a strong argument that the outcome of McConnell can be explained only by reference to such a principle. ${ }^{8}$

1 Buckley v. Valeo, 424 U.S. 1 (1976).

2 See J. Skelly Wright, Money and the Pollution of Politics: Is the First Amendment an Obstacle to Political Equality?, 82 COLUM. L. Rev. 609, 631-32 (1982); J. Skelly Wright, Politics and the Constitution: Is Money Speech?, 85 YALE L.J. 1001, 1005 (1976); see also Burt Neuborne, Buckley's Analytical Flaws, 6 J.L. \& POL'Y 111, 115 (1997).

${ }^{3}$ See, e.g., Nixon v. Shrink Mo. Gov't PAC, 528 U.S. 377, 378 (2000) (Stevens, J., concurring) ("Money is property; it is not speech"); id. at 413-18 (Thomas, J., dissenting) (arguing that result of contribution limits "is simply the suppression of political speech"); Colo. Republican Fed. Campaign Comm. v. Fed. Election Comm'n, 518 U.S. 604, 649 (1996) (Stevens, J., dissenting) ("[M]oney is not always equivalent to or used for speech, even in the context of political campaigns." (quoting Buckley, 424 U.S. at 263 (White, J., concurring in part and dissenting in part))); id. at 635-40 (Thomas, J., concurring in part and dissenting in part) (arguing that "contribution limits infringe as directly and as seriously upon freedom of political expression and association as do expenditure limits").

${ }^{4}$ McConnell v. Fed. Election Comm'n, 540 U.S. 93 (2003).

5 Stephen Breyer, Madison Lecture: Our Democratic Constitution, 77 N.Y.U. L. REV. 245, 252 (2002).

6 Buckley, 424 U.S. at 48-49.

7 See Richard L. Hasen, Buckley Is Dead, Long Live Buckley: The New Campaign Finance Incoherence of McConnell v. Federal Election Commission, 153 U. PA. L. REV. 31, 57-58 (2004).

${ }^{8}$ Id. at 58-59. There is also a good argument that Buckley's own anticorruption 
These are familiar observations in discussions of campaign finance regulation. What is less often noticed is that the same issues - the connection between money and speech and the extent to which there is a First Amendment interest in the proper functioning of political forums - are central to another, less prominent line of Supreme Court cases. These are the cases that establish a First Amendment right against compelled subsidization.'

The basic idea of the compelled subsidization doctrine is that the First Amendment prohibits the government from requiring some individuals to subsidize the First Amendment activities of others. To oversimplify: you cannot be forced to pay for someone else's speech. Those who argue for such a First Amendment right often quote Thomas Jefferson's pronouncement that "to compel a man to furnish contributions of money for the propagation of opinions which he disbelieves is sinful and tyrannical. ${ }^{\prime 10}$ To date, the Supreme Court has considered the constitutionality of compelled subsidization in four contexts: statutorily enabled agency shops (where employees are required to subsidize union political activities), integrated bars (where attorneys are required to pay for the legislative activities of a state bar association), industry trade associations (where industry members are required to help fund generic advertising campaigns), and state university student activity fees (where students are required to subsidize the political and ideological activities of student organizations). It has also been argued that the compelled subsidization doctrine should limit the use of Interest on Lawyer Trust Account ("IOLTA") funds, ${ }^{11}$ mandatory pro bono requirements,

rationale tacitly relies on a political equality principle. See David A. Strauss, Corruption, Equality, and Campaign Finance Reform, 94 CoLUM. L. REV. 1369, 1369-70 (1994); David A. Strauss, What Is the Goal of Campaign Finance Reform?, 1995 U. CHI. LEGAL F. 141, 143 (1995).

9 Leslie Gielow Jacobs also explored the possible connection between the First Amendment's approaches to campaign finance regulation and to compelled subsidization. Leslie Gielow Jacobs, The Link Between Student Activity Fees and Campaign Finance Regulations, 33 IND. L. REV. 435 (2000). While the argument in this Article is consonant with Jacobs's emphasis on the First Amendment's protections against "governmental favoritism of certain viewpoints in the marketplace of ideas," it departs from Jacobs on a number of particulars, not the least being whether such favoritism is " $[t]$ he primary danger against which the free speech clause protects." Id.

${ }_{10}$ Thomas Jefferson, The Statute of Virginia for Religious Freedom, in THE VIRGINIA STATUTE FOR RELIGIOUS FREEDOM: ITS EVOLUTION AND CONSEQUENCES IN AMERICAN HISTORY, at xvii (Merrill Peterson \& Robert Vaughan eds., 1988); see infra notes 99, 114.

"See Terence E. Doherty, The Constitutionality of IOLTA Accounts, 19 WHITTIER L. REV. 487 (1998); David J. Hrina, Comment, The Future of IOLTA: Has the Death Knell Been Sounded for Mandatory IOLTA Programs?, 32 AKRON L. REv. 301 (1999); Risa I. Sackmary, Note, IOLTA'S Last Obstacle: Washington Legal Found. v. Massachusetts Bar Found.'s Faulty Analysis of Attorneys' First Amendment Rights, 2 J.L. \& POL'Y 187 (1994). 
continuing legal education requirements, ${ }^{13}$ the charitable donations of utility companies, ${ }^{14}$ cigarette surtaxes used to fund anti-smoking campaigns, ${ }^{15}$ and some forms of public campaign financing. ${ }^{16}$

Since announcing the right against compelled subsidization in $1977,{ }^{17}$ a majority of the Supreme Court has remained willing to affirm it. Over the years, however, the Court has employed different standards to decide compelled subsidization cases. And it has never settled on a single account of the doctrine's theoretical underpinnings - just what First Amendment interest is threatened by compelled subsidization. In recent years, tensions have come to a head. In three separate decisions, Glickman v. Wileman Bros. \& Elliot (1997), ${ }^{18}$ Board of Regents v. Southworth (2000), ${ }^{19}$ and United States $v$. United Foods (2001), ${ }^{20}$ the Supreme Court has made significant and, at times, inconsistent amendments to the doctrine, without indicating how the new standards are to be reconciled with the old or applied to novel cases. At present, it is difficult to discern what rules govern compelled subsidization and where the constitutional limits lie.

The root cause of the current confusion is the Supreme Court's failure to provide a coherent account of the First Amendment harm of compelled subsidization. Part I of this Article describes the present state of the doctrine. It identifies a number of practical problems, especially the imprecisions in and conflicts between the Court's holdings that leave it unclear how lower courts should decide novel cases. Part II is a critical discussion of the two most common arguments for a First Amendment right against compelled subsidization: that compelled subsidization infringes on dissenters' freedom of belief and that it restricts their freedom of expression. A comparison of compelled subsidization with the First Amendment interests at stake in compelled speech shows that neither argument withstands scrutiny and that this deficiency in theory

12 See John C. Scully, Mandatory Pro Bono: An Attack on the Constitution, 19 HOFSTRA L. REV. 1229 (1991).

13 See Kari M. Dahlin, Note, Actions Speak Louder than Thoughts: The Constitutionally Questionable Reach of the Minnesota CLE Elimination of Bias Requirement, 84 MINN. L. REv. 1725 (2000).

${ }^{14}$ See R. Paul Gee, Note, Who Pays for Charitable Contributions Made by Utility Companies?, 12 ENERGY L.J. 363 (1991).

${ }_{15}$ See R.J. Reynolds Tobacco Co. v. Shewry, 384 F.3d 1126 (9th Cir. 2004).

16 See May v. McNally, 55 P.3d 768 (Ariz. 2002).

17 See Abood v. Detroit Bd. of Educ., 431 U.S. 209 (1977).

18 Glickman v. Wileman Bros. \& Elliot, 521 U.S. 457 (1997).

19 Bd. of Regents of Univ. of Wis. Sys. v. Southworth, 529 U.S. 217 (2000).

${ }^{20}$ United States v. United Foods, Inc., 533 U.S. 405 (2001). 
is the cause of much of the confusion in practice. Part III argues that if there is a First Amendment right against compelled subsidization, it is grounded not in the liberty interests of dissenting individuals, but in compelled subsidization's potential harm to public political discourse. This brings a fresh perspective on the idea that there is a First Amendment interest in "democratizing the influence of money on the electoral process," and suggests a new, more general test for compelled subsidization cases. Part IV briefly discusses what it would take to transpose the results from a reformed compelled subsidization doctrine into the register of campaign finance regulation.

A decision like McConnell comes along once in a generation. At least for the next few years, lower courts probably will be left to their own devices in grappling with its implications for campaign finance regulation, including the extent to which there is a First Amendment interest in regulating equality of influence or participation in the electoral sphere. The compelled subsidization doctrine provides an opportunity to address these issues without losing oneself in the doctrinal and political complexities of campaign finance. The Supreme Court will revisit the doctrine this Term in Veneman $v$. Livestock Marketing Ass'ns, a case involving the requirement that beef producers pay for generic beef advertising. ${ }^{21}$ One can only hope that the Court granted certiorari in Veneman to deal at least with the confusion in the industryassociation advertising cases. With luck, it will also take the opportunity to clarify the doctrine as a whole. ${ }^{22}$ By clearing away the underbrush surrounding compelled subsidization, it may be possible to develop tools to attack the jungle of campaign finance.

\section{Problems in Practice: Difficulties With the Doctrine as it NoW STANDS}

The compelled subsidization doctrine is situated at the periphery of First Amendment jurisprudence and has received little sustained

${ }^{21}$ Veneman v. Livestock Mktg. Ass'n, 335 F.3d 711 (8th Cir. 2003), cert. granted, 124 S. Ct. 2389 (U.S. May 24, 2004) (No. 03-1164).

${ }^{22}$ The Solicitor General's petition for certiorari in the case focuses on another question, left undecided in United Foods: whether such industry advertising programs are government speech. Pet. for Cert. at 12-24, Veneman v. Livestock Mktg. Ass'n, 335 F.3d 711 (8th Cir. 2003), cert. granted, 124 S. Ct. 2389 (U.S. May 24, 2004) (No. 03-1164). If the Court were to decide the case on this issue, finding that the program at issue is government speech, it would not have to address the compelled subsidization question. This Article argues below, however, that basically the same test should apply under either characterization. 
attention, either from courts or from commentators. ${ }^{23}$ As a result, its branches have spread faster than its roots. This part describes the tree from the trunk up - the contexts in which the Supreme Court has applied the compelled subsidization doctrine and the tests it has developed to decide cases. It turns out that the motley collection of Supreme Court holdings makes it all but impossible to say how courts should decide novel cases. Parts II and III then turn to the roots. Part II examines the principal arguments the Court and individual justices have used to justify the doctrine. Part III proposes an alternative account of its fundament and recommends pruning a few branches.

The Supreme Court first considered the idea of a First Amendment right against compelled subsidization in Railway Employee's Department $v$. Hanson, a 1956 case involving dissenting railway employees' objections to mandatory union dues under a federally enabled union shop agreement. $^{24}$ The Court avoided the constitutional issue in Hanson. ${ }^{25}$ And it avoided the issue again in two 1961 decisions, International Ass' $n$ of Machinists $v$. Street, ${ }^{26}$ which also concerned union shop agreements, and Lathrop v. Donahue, ${ }^{27}$ which dealt with integrated state bars.

It was not until 1977, in Abood v. Detroit Board of Education, that a majority of the Court was willing to affirm a First Amendment right

${ }^{23}$ The first law review article devoted to the general grounds of the compelled subsidization doctrine was Norman L. Cantor's Forced Payments to Service Institutions and Constitutional Interests in Ideological Non-association, 36 RUTGERS L. REV. 3 (1983). The doctrine has since been given sustained attention by Leslie Gielow Jacobs in Pledges, Parades, and Mandatory Payments, 52 RUTGERS L. REV. 123 (1999) and Jacobs, supra note 9, and by Howard Wasserman in Compelled Expression and the Public Forum Doctrine, 77 TUL. L. REV. 163 (2002). Other commentators simply treat the compelled subsidization cases as a species of compelled speech cases. See, e.g., Abner S. Greene, The Pledge of Allegiance Problem, 64 FORDHAM L. REV. 451, 467 (1995); Robert D. Kamenshine, Reflections on Coerced Expression, 34 LAND \& WATER L. R5V. 101, 108-10 (1999). One of the conclusions of this Article is that if the compelled subsidization doctrine has a secure foundation, it is different from that of the compelled speech doctrine.

${ }^{24}$ Ry. Employees' Dep't v. Hanson, 351 U.S. 225 (1956).

25 See id.

${ }^{26}$ Int'l Ass'n of Machinists v. Street, 367 U.S. 740 (1961).

${ }^{27}$ Lathrop v. Donahue, 367 U.S. 820 (1961). While these cases avoided deciding the constitutional issue, their statutory construction and strong dissenting and concurring opinions from Black, Douglas, Frankfurter, and Harlan laid the groundwork for the constitutional decisions that followed. See Lehnert v. Ferris Faculty Ass'n, 500 U.S. 507, 516 (1991) ("Although [it is a case] of statutory construction, Street [is] instructive in delineating the bounds of the First Amendment in this area as well."); id. at 555 (Scalia, J., concurring with judgment in part and dissenting in part) ("Street [was a statutory case], but there is good reason to treat [it] as merely reflecting the constitutional rule suggested in Hanson and later confirmed in Abood. Street adopted a construction of the [Railway Labor Act] nowhere suggested in its language, to avoid 'serious doubt of [its] constitutionality.'" (quoting Street)). 
against compelled subsidization. ${ }^{28}$ In a series of decisions between 1977 and 1991, the Court developed the doctrine with respect to two types of cases. The first group of cases involved government-enabled union shop agreements, in which dissenting employees objected to requirements that they help pay for union speech with which they disagreed. ${ }^{29}$ The second dealt with integrated bars, in which attorneys complained of being required to pay dues that supported the state bar association's expressive activities. ${ }^{30}$ During this period, the Court's opinions focused on the uses to which challenged payments were put. Abood, the case that established a First Amendment right against compelled subsidization, identified the following salient factors:

We do not hold that a union cannot constitutionally spend funds for the expression of political views, on behalf of political candidates, or toward the advancement of other ideological causes not germane to its duties as collective-bargaining representative. Rather, the constitution requires only that such expenditures be financed from charges, dues, or assessments paid by employees who do not object to advancing those ideas and who are not coerced into doing so. ${ }^{31}$

This statement emphasizes two questions: Are expenditures germane to the activity for which payments are compelled? And, are they political or ideological in nature? Abood held that if an expenditure is both nongermane and funds political or ideological activities, then it violates dissenters' First Amendment rights. ${ }^{32}$ As the cases progressed, this approach was refined and generalized until in 1991, in Lehnert $v$. Ferris

28 Abood v. Detroit Bd. of Educ., 431 U.S. 209, 235-36 (1977).

${ }^{29}$ Lehnert, 500 U.S. 507; Ellis v. Bhd. of Ry. Clerks, 466 U.S. 435 (1984); Abood, 431 U.S. 209.

${ }^{30}$ Keller v. State Bar of Cal., 496 U.S. 1 (1990). In addition to these cases and subsequent cases discussed below, the Supreme Court has ruled on the procedural safeguards necessary to protect the rights of dissenting union members and provided statutory interpretations that parallel the First Amendment compelled subsidization doctrine. Air Line Pilots Ass'n v. Miller, 523 U.S. 866 (1998); Communication Workers of Am. v. Beck, 487 U.S. 735 (1988); Chi. Teachers Union v. Hudson, 475 U.S. 292 (1986); Minn. State Bd. of Colleges v. Knight, 465 U.S. 271 (1984); Bhd. of Ry. \& S.S. Clerks v. Allen, 373 U.S. 113 (1963); Street, 367 U.S. 740; Hanson, 351 U.S. 225.

${ }^{31}$ Abood, 431 U.S. at 235-36 (italics added); see also id. at 236 (finding relevant distinction to be that "between collective-bargaining activities, for which contributions may be compelled, and ideological activities unrelated to collective bargaining, for which such compulsion is prohibited."). Keller employed an identical test. Keller, 496 U.S. at 14 ("The State Bar may . . . constitutionally fund activities germane to those goals out of the mandatory dues of all members. It may not, however, in such manner fund activities of an ideological nature which fall outside of those areas of activity.").

${ }^{32}$ Abood, 431 U.S. at 235-36. 
Faculty Ass'n, a majority of the Court agreed with the following formulation:

chargeable activities must (1) be "germane" to collective-bargaining activity; (2) be justified by the government's vital policy interest in labor peace and avoiding "free riders"; and (3) not significantly add to the burdening of free speech that is inherent in the allowance of an agency or union shop.

To further generalize: challenged expenditures violate the First Amendment rights of dissenters unless they are (1) germane to (2) a vital governmental interest and (3) do not significantly add to the burden on dissenters' free speech interests inherent in the furtherance of that interest. $^{34}$

In recent years, the Court has moved on to other types of compelled subsidization - mandatory assessments for generic industry advertising and state university student-activity fees. In doing so, the Court has departed from the Abood-Lehnert approach, as discussed below. Nonetheless, Lehnert represents a sort of high-water mark in the development of the compelled subsidization doctrine, for it provides the most generic statement of when compelled subsidization violates the First Amendment, a test that seemingly still applies in the union and state bar cases. ${ }^{35}$ But there are two significant problems with the Lehnert test.

The first is that germaneness is a particularly vague standard. Lehnert does not specify how germane an expenditure must be - how closely it must relate to the government's legitimate purpose - to survive constitutional scrutiny. As the Court has since noted, this problem was

33 Lehnert, 500 U.S. at 519.

34 On the way to Lehnert, the Court formulated a somewhat more permissive test. Ellis $v$. Brotherhood of Railway Clerks held that the first question to ask is whether the expenditure is germane to the union's collective bargaining activities (i.e., to the legitimate government interest in compelling dissenters to pay). Ellis, 466 U.S. at 456 . If expenditures are not germane, then they are not allowed. If germane, a court must then ask "whether these expenses involve additional interference with the First Amendment interests of objecting employees, and, if so, whether they are nonetheless adequately supported by a governmental interest." Id. at 456 . That is, germane expenditures are constitutional only if the governmental interest in compelling payments outweighs the harm to dissenters' First Amendment rights. Lehnert replaced this balancing of the government's interest against the First Amendment harm with two separate requirements: a vital governmental interest and no significant addition to the burden on dissenters' free speech.

35 See, e.g., Otto v. Penn. State Educ. Ass'n-NEA, 330 F.3d 125, 135-40 (3d Cir. 2003) (union dues); Romero v. Colegio De Abogados De Puerto Rico, 204 F.3d 291, 296-303 (1st Cir. 2000) (state bar). 
manifest in the conflicting opinions in Lehnert itself. ${ }^{36}$ Justice Marshall, in a partial dissent, argued that any expenditure "reasonably designed to influence the public employer's position at the bargaining table" was germane to a teachers' union's collective bargaining activities. ${ }^{37} \mathrm{He}$ concluded that lobbying, public relations campaigns in support of the teaching profession in general, and litigation outside of the collective bargaining group were all germane to the state's legitimate purpose in promoting the agency-shop agreements. ${ }^{38}$ Justice Scalia, also dissenting in part, considered a union expenditure germane only if "incurred for the conduct of activities in which the union owes a duty of fair representation to nonmembers being charged." ${ }^{39}$ He therefore found almost all of the challenged union expenditures - including nonpolitical union publications, union conventions, national collective bargaining expenses and the costs of preparing for a strike - nongermane and nonfundable by the contributions of dissenting employees. ${ }^{40}$ The Lehnert majority wanted a concept of germaneness lying somewhere between these extremes, for it disallowed expenditures that Marshall would have permitted and allowed expenditures Scalia considered unconstitutional. ${ }^{41}$ But it failed to specify just where on the spectrum between Marshall and Scalia its concept of germaneness lay and thus provided little guidance as to how the criterion should be applied.

A second difficulty comes with the third step of the Lehnert test, which requires that expenditures "not significantly add to the burdening of free speech that is inherent in the allowance" of the compelled payments. ${ }^{42}$ In order to determine whether a given government action burdens First

${ }_{36}$ Bd. of Regents v. Southworth, 529 U.S. 217, 231-32 (2000) ("Even in the context of a labor union, whose functions are, or so we might have thought, well known and understood by the law and the courts after a long history of government regulation and judicial involvement, we have encountered difficulties in deciding what is germane and what is not. The difficulty manifested itself in our decision in Lehnert . . where different members of the Court reached varying conclusions regarding what expressive activity was or was not germane to the mission of the association.").

The various opinions in Lehnert were foreshadowed in the different understandings of germaneness in Street. Where the plurality found that political activities were not germane to the union's collective bargaining activities, Frankfurter emphasized "the practical necessity for unions to participate in . . . political activities." Int'l Ass'n of Machinists v. Street, 367 U.S. 740, 768, 811 (Frankfurter, J., dissenting).

${ }^{37}$ Lehnert, 500 U.S. at 533 (Marshall, J., concurring in part and dissenting in part).

${ }_{38}$ Id. at 535-37.

${ }^{39}$ Id. at 558 (Scalia, J., concurring in part and dissenting in part).

40 Id. at 550-58.

41 See id. at 524-27 (criticizing Scalia's proposed germaneness test).

42 Id. at 519. This third prong presumably explains why Abood emphasized the political or ideological nature of certain expenditures. Id. 
Amendment interests, we must know what the relevant interests are. The problem, which Part II explores at length, is that the Court has never settled on a good account of just how compelled subsidization threatens the First Amendment rights of dissenting payers. Instead, it has vacillated between two approaches. The first holds that compelled subsidization infringes on dissenters' freedom of belief by requiring them to act contrary to their conscience. The second maintains that compelled subsidization is simply another form of compelled speech, and therefore violates dissenters' First Amendment right to remain silent.

That these different accounts of the relevant First Amendment interest can produce conflicting results as to how much payments "add to the burdening of free speech" was vividly demonstrated by the first postLehnert decision, Glickman v. Wileman Bros. \& Elliot, Inc. ${ }^{43}$ Though Wileman did not apply the Lehnert standard in any straightforward way, its outcome turned on the question of whether there was a burdening of First Amendment interests. The case concerned federally mandated assessments on fruit growers that went toward funding generic fruit advertising. Justice Stevens, writing for the majority, reasoned that compelled subsidization implicates the First Amendment only to the extent that it interferes with dissenters' freedom of belief.

Abood, and the cases that follow it, did not announce a broad First Amendment right not to be compelled to provide financial support for any organization that conducts expressive activities. Rather, Abood merely recognized a First Amendment interest in not being compelled to contribute to an organization whose expressive activities conflict with one's "freedom of belief."

The majority concluded that the First Amendment right against compelled subsidization extends only to cases in which the subsidized message creates for the dissenting payer a "crisis of conscience." ${ }^{145}$ While "political or ideological disagreement with the content of the message" can produce such a crisis, the dissenting fruit growers' objections to the advertisements they were required to help fund did not rise to that level

${ }^{43}$ Glickman v. Wileman Bros. \& Elliot, Inc., 521 U.S. 457 (1997).

44 Id. at 471 (quoting Abood, 431 U.S. at 235); see also id. at 472 ("IC]ompelled contributions for political purposes unrelated to collective bargaining implicated First Amendment interests because they interfere with the values lying at the 'heart of the First Amendment ... the notion that an individual should be free to believe as he will, and that in a free society one's beliefs should be shaped by his mind and his conscience rather than coerced by the State." (quoting Abood, 431 U.S. at 234-35)).

45 Id. at 472. 
and thus did not implicate the First Amendment. ${ }^{46}$

Justice Souter's dissent, on the other hand, viewed compelled subsidization as a species of compelled speech, which gave rise to the following three-step argument. First, commercial speech is due some degree of First Amendment protection. ${ }^{47}$ Second, the Court's compelledspeech cases have established that "compelling cognizable speech officially is just as suspect as suppressing it, and is typically subject to the same level of scrutiny." ${ }^{\prime 48}$ Thus compelled commercial speech is subject to the same level of scrutiny as restricted commercial speech. Third, compelled subsidization is a species of compelled speech. ${ }^{49}$ It is then a short step to the conclusion that "[s]ince a commercial speaker (who does not mislead) may generally promote commerce as he sees fit, the government requires some justification ... before it may force him to subsidize commercial speech to which he objects. ${ }^{150}$

The different accounts of the First Amendment interests at stake in Wileman lead the majority and dissent to radically different conclusions as to how the case should have come out. The problem is that we have not been told just what First Amendment interests the right against compelled subsidization is meant to protect. And, without knowing that, it is impossible to say when compelled subsidization "significantly add[s] to the burdening of free speech that is inherent" in the legitimate program at issue. ${ }^{51}$

In recent years, dissatisfaction with the germaneness standard, along with the Court's inability to settle on a single account of the relevant First Amendment interest, has led to a breakdown of the three-part Lehnert test. A third significant problem with the current state of the doctrine is that the cases decided since Lehnert have left uncertain what test courts should apply to novel cases.

${ }^{46}$ Id. For support of the proposition that the right not to subsidize extends only to political or ideological speech, the majority appealed to Lehnert's finding that union expenditures for nonpolitical publications do not violate the First Amendment rights of dissenting members. Id. at 473 (citing Lehnert, 500 U.S. at 529).

${ }^{47}$ Id. at 478-80 (Souter, J., dissenting) (citing inter alia Va. St. Bd. of Pharmacy v. Va. Citizens Consumer Council, 425 U.S. 748 (1976)).

48 Id. at 481 .

49 Id. at 481-82 ("As a familiar corollary to the principle that what may not be suppressed may not be coerced, we have recognized . . . that individuals have a First Amendment interest in freedom from compulsion to subsidize speech and other expressive activities undertaken by private and quasi-private organizations."), id. at 487 ("[S]peech significant enough to be protected at some level is outside the government's power to coerce or to support by mandatory subsidy without further justification.").

so Id. at 487.

${ }^{51}$ Lehnert v. Ferris Faculty Ass'n, 500 U.S. 507, 519 (1991). 
This is most apparent in the competing logics of the two post-Lehnert decisions on the compelled subsidization of commercial speech, Wileman and United States $v$. United Foods. ${ }^{52}$ As already noted, Wileman held in 1997 that federally mandated assessments to fund fruit advertising did not infringe on the First Amendment rights of dissenting fruit growers. ${ }^{53}$ Four years later, however, United Foods concluded that federally mandated assessments to fund mushroom advertising violated the First Amendment rights of dissenting mushroom producers. ${ }^{54}$ Justice Kennedy's United Foods opinion attempts to explain the different outcomes by emphasizing the fact that the advertising at issue in Wileman was part of a broader program of industry regulation, whereas the United Foods assessments on mushroom growers were used almost solely to fund advertising. ${ }^{55}$ But a cursory reading of the opinions in these cases reveals deeply conflicting logics, suggesting that this distinction did not make the difference in their outcomes. ${ }^{56}$

The different holdings are better explained by the fact that United Foods jettisoned Wileman's crisis-of-conscience test. As noted above, the Wileman majority categorically rejected the argument that compelled subsidization is a form of compelled speech. ${ }^{57}$ It reasoned instead that compelled subsidization implicates the First Amendment only to the extent that it interferes with dissenters' freedom of belief, which is to say, only when it creates for the dissenting payer a "crisis of conscience.

52 United States v. United Foods, Inc., 533 U.S. 405 (2001).

53 Wileman, 521 U.S. at 472.

${ }^{54}$ United Foods, Inc., 533 U.S. at 415-16.

55 Id. at 411-12.

${ }^{56}$ See id. at 419-29 (Breyer, J., dissenting); infra p. 1091. The causal-historical explanation of the divergent outcomes lies in the decisions of Kennedy and Stevens to switch sides on the issue. Both found the Wileman advertising programs constitutional (Stevens writing majority opinion, which Kennedy joined) and the United Foods advertising programs unconstitutional (Kennedy writing majority opinion, which Stevens joined).

${ }_{57}$ Glickman v. Wileman Bros. \& Elliot, Inc., 521 U.S. 457, 469 (1997) ("[T]he marketing orders ... do not compel any person to engage in any actual or symbolic speech"); $i d$. at 470-71 ("The use of assessments to pay for advertising does not require respondents to repeat an objectionable message out of their own mouths ... require them to use their own property to convey an antagonistic ideological message . . . force them to respond to a hostile message when they 'would prefer to remain silent,' . . . or require them to be publicly identified or associated with another's message .... Respondents are not required themselves to speak, but are merely required to make contributions for advertising." (citing Pac. Gas \& Elec. v. Pub. Util. Comm'n, 475 U.S. 1, 18 (1986), PruneYard Shopping Ctr. v. Robins, 447 U.S. 74, 88 (1980), and W. Va. St. Bd. of Educ.v. Barnette, 319 U.S. 624, 632 (1943))).

${ }^{58}$ Id. at 472. Wasserman suggests that the ratio decidendi of Wileman was that the Court's "assum[ption] that the complaining producers would agree with [the] general idea" of the challenged advertising, which simply encouraged consumers to buy California 
United Foods did away with Wileman's crisis-of-conscience approach, reasoning that "there is no apparent principle which distinguishes out of hand minor debates about whether a branded mushroom is better than any mushroom" from supposedly more significant disagreements. ${ }^{59}$ This suggests that the Court no longer adheres to the freedom-of-belief account of the right not to subsidize.

United Foods did not, however, return to the freedom-of-speech account of Souter's Wileman dissent. ${ }^{60}$ Without further discussing the grounds of the compelled subsidization doctrine, Kennedy's opinion instead introduces a new germaneness test: an expenditure must not only be germane to a legitimate purpose (the standard used by earlier courts $^{61}$ ), but it must be germane to a non-expressive program. The expenditures at issue in United Foods fail this test because "the expression respondent is required to support is not germane to a purpose related to an association independent from the speech itself." ${ }^{\prime 62}$ The majority

tree fruit. Wasserman, supra note 23 , at 180 . I would argue that Wasserman here neglects Wileman's focus on the potential for a "crisis of conscience."

59 United Foods, Inc., 533 U.S. at 411; see also id. at 410 ("The subject matter of the speech may be of interest to but a small segment of the population; yet those whose business and livelihood depend in some way upon the product involved no doubt deem First Amendment protection to be just as important for them as it is for other discrete, little noticed groups in a society which values the freedom resulting from speech in all its diverse parts.").

United Foods later cites Abood for the proposition that "speech need not be characterized as political before it receives First Amendment protection." Id. at 413 (citing Abood, 431 U.S. at 232). The opinion refers here to a section of the Abood opinion that concerned the plaintiffs' argument that because they were public employees and because bargaining in the public sector is inherently political, they suffered a more significant First Amendment harm than the plaintiffs in either Hanson or Street. Abood, 431 U.S. at 229-32. The Abood Court rejected this argument with the remark that "[n]othing in the First Amendment or our cases discussing its meaning makes the question whether the adjective "political' can properly be attached to those beliefs the critical constitutional inquiry." Id. at 232. But the Abood Court's response to this preliminary side issue should not be allowed to obscure its emphasis in the main part of the opinion on the political and ideological nature of the union's speech. Id. at 234-36.

${ }_{60}$ Stevens, concurring, argued that compelled subsidization should not be considered a form of compelled speech, but did not identify his preferred theory of the doctrine or say whether he still held onto his Wileman opinion. United Foods, Inc., 533 U.S. at 417 (Stevens, $\mathrm{J}$. , concurring). Thomas, concurring, argued that compelled subsidization is a form of compelled speech. Id. at 418-19 (Thomas, J., concurring).

${ }_{61}$ See, e.g., Abood, 431 U.S. at 217-22 (discussing government's interest in promoting agency shops, as established by Hanson and Street); id. at 224-25 (relating those interests to union's collective-bargaining activities); Keller v. State Bar, 496 U.S. 1, 14 (1990) (finding that expenditures must serve legitimate purpose of integrated bar, which is to improve quality of legal profession).

${ }_{22}$ United Foods, Inc., 533 U.S. at 415 . Stevens states a similar rule in his concurrence: "a compelled subsidy is permissible when it is ancillary, or 'germane,' to a valid cooperative 
opinion does not provide an argument for this new constitutional criterion, but Stevens suggests one in his concurrence:

The incremental impact on the liberty of a person who has already surrendered far greater liberty to the collective entity (either voluntarily or as a result of permissible compulsion) does not, in my judgment, raise a significant constitutional issue if it is ancillary to the main purpose of the collective program. . . . The naked imposition of such compulsion, like naked restraint on speech itself, seems quite different to me. ${ }^{63}$

The apparent idea behind Stevens's argument was succinctly captured by Karl Llewellyn: "An institution we could not honor naked, we should not dare to strip.", ${ }^{\prime 64}$

The tension between the Court's industry advertising cases can be summarized as follows. While United Foods did not overrule Wileman, it explicitly rejected the logic on which the earlier case had been decided. But if we no longer have the crisis-of-conscience test, it is difficult to see how the outcome in Wileman can stand. Moreover, instead of providing an alternative to Wileman's general crisis-of-conscience test, United Foods introduces a new test that applies only in very specific circumstances, namely, where compelled payments fund exclusively expressive activities, as opposed to a broader regulatory program of which expressive activities are merely a part. Finally, United Foods leaves it unclear just why the First Amendment includes a right against compelled subsidization. While implicitly rejecting Wileman's emphasis on freedom of belief, it does not suggest an alternative account of the right. Justices Stevens and Thomas suggest sharply different answers to that question in separate concurrences. ${ }^{65}$ This is evidence that there is no

endeavor." Id. at 418 (Stevens, J., concurring).

${ }^{63}$ Id. at 418 (Stevens, J., concurring). In a footnote to the above, Stevens makes the striking statement that not only is compulsion as bad as restriction, but "government compulsion to finance objectionable speech imposes a greater restraint on liberty than government regulation of money used to subsidize the speech of others." Id. at $418 n$. $^{* *}$. Stevens provides no argument for this proposition, but perhaps felt it necessary to justify his apparently contrary opinions about restrictions on campaign contributions. See Nixon v. Shrink, 528 U.S. 377, 398-99 (Stevens, J., concurring) (doubting whether campaign contributions deserve same level of protection against restriction as speech they help fund).

${ }^{64}$ KARL LleWELlyN, THE BRAMBLE BUSH 125 (2D ED. 1951).

${ }_{65}$ United Foods, Inc., 533 U.S. at 417 (Stevens, J., concurring) (agreeing with Breyer, in dissent, that "the program at issue in this case ... 'does not compel speech itself; it compels the payment of money'"); id. at 418-19 (Thomas, J., concurring) (affirming his view "that paying money for the purpose of advertising involves speech, and ... compelling speech raises a First Amendment issue just as much as restricting speech." (internal quotation marks omitted)). 
longer a majority opinion among the Court as to why there is a First Amendment right not to subsidize.

These unresolved inconsistencies have left lower courts without any clear guidance on how to decide industry-association advertising cases. The confusion is exemplified by the Eighth Circuit's decision in Livestock Marketing Ass'n v. Department of Agriculture. ${ }^{66}$ After explaining that it was "duty-bound to reconcile and apply the precedents of the Supreme Court to the best of [its] ability, ${ }^{\prime 67}$ the panel guessed that if given the chance, the United Foods majority would have applied the Central Hudson test for commercial speech. ${ }^{68}$ It then read both the germaneness standard from the Court's early compelled subsidization cases and Southworth's viewpoint-neutrality test (see below) as methods for determining "whether the regulation directly advances the governmental interest asserted, and whether it is not more extensive than necessary to serve that interest. ${ }^{\prime \prime 9}$ But then, rather than applying these rules, the Eighth Circuit declined to "engage in such a line-drawing exercise, ${ }^{\prime 70}$ and simply found that the challenged beef marketing program was identical in all material respects to the mushroom checkoff program in United Foods, and therefore violated the First Amendment. ${ }^{71}$ As noted above, the Supreme Court has granted certiorari in this case.

For the most part, both Wileman and United Foods ignore the three-part Lehnert test. One can read each case, however, as attempting in its own way to modify that standard. ${ }^{72}$ The Court's third recent compelled

${ }_{66}$ Livestock Mktg. Ass'n. v. United States Dep't of Agric., 335 F.3d 711 (8th Cir. 2004).

67 Id. at 725 .

68 Id. at 722; Cent. Hudson Gas \& Elec. Corp. v. Pub. Serv. Comm'n, 447 U.S. 557 (1980). In considering the possible applicability of the Central Hudson test, the United Foods Court did note that the government had not raised that argument as a reason not to apply it in that case, but it also emphasized that the Central Hudson approach had "been subject to some criticism" by members of the Court. United Foods, Inc., 533 U.S. at 409-10. And nowhere did the United Foods majority suggest that the Central Hudson test would be appropriate or that it was overruling Wileman's conclusion that "[i]t was ... error for the Court of Appeals to rely on Central Hudson for the purpose of testing the constitutionality of market order assessments for promotional advertising." Glickman v. Wileman Bros. \& Elliot, 521 U.S. 457, 474 (1997). Breyer, in dissent, suggested that the special considerations applicable to commercial speech should also apply to the dissenting mushroom growers, United Foods, Inc., 533 U.S. at 426-27 (Breyer, J., dissenting), but concluded that the program at issue would pass the Central Hudson test, id. at 429-31.

69 Livestock Mktg. Ass'n, 335 F.3d at 723 (quoting Central Hudson, 447 U.S. at 566).

70 Id. at 725 .

71 Id. at $725-26$.

72 Souter, dissenting from Wileman, criticizes the majority for not considering the second two prongs of the Lehnert test. Wileman, 521 U.S. at 485 (Souter, J., dissenting). But given the basic premise of the majority's opinion - that non-ideological speech cannot offend the First Amendment rights of those forced to pay for it - the question of whether 
subsidization decision, Board of Regents $v$. Southworth, involves a more radical departure. ${ }^{73}$

Southworth considered whether a state university's mandatory student fees, used to fund the political and ideological speech of student organizations, violated the First Amendment rights of dissenting students - a question that had divided the circuits ${ }^{74}$ and given rise to a deluge of student notes. ${ }^{75}$ The Seventh Circuit applied the three-part

the speech is ideological or not directly addresses the test's third prong: whether challenged assessments significantly add to the burdening of free speech. Thus one might read Wileman not as introducing a special test for commercial speech, but as applying the general test for compelled speech to argue that the compelled subsidization of strictly commercial speech cannot run afoul of the First Amendment.

Incredibly, Kennedy's United Foods opinion never even mentions Lehnert. However, as argued above, the reasoning can be viewed as a modification of the traditional germaneness test - the first step in Lehnert's three-pronged test. It seems that after United Foods, an expenditure for expressive activities passes the first prong of the Lehnert test only if it is germane to the state's legitimate purpose in imposing mandatory payments (the original criterion) and to a broader program that includes non-expressive components (the United Foods innovation).

73 Bd. of Regents v. Southworth, 529 U.S. 217 (2000).

${ }^{4}$ See id. at 227-28 (citing cases).

75 See, e.g., Donna M. Cote, Comment, The First Amendment and Compulsory Funding of Student Government Political Resolutions at State Universities, 62 U. CHI. L. REV. 825 (1995); Travis Crabtree, Note, Southworth v. Grebe: The Inquisition of the First Amendment, 36 Hous. L. REV. 1093 (1999); David E. Frank, Note, First Amendment Protection from Mandatory Subsidization of Political Speech in Public Colleges and Universities: The Marketplace Just Got a Lot Less Expensive, 48 DRAKE L. REV. 359 (2000); Michael J. Hamblin, Note, Southworth v. Grebe: Why the Seventh Circuit's Decision Was the Correct Response to Rosenberger v. Rector and Visitors of the University of Virginia, 46 WAYNE L. REV. 361 (2000); Marita Erbeck Aimee Hamoy, Survey, Bd. of Regents of the Univ. of Wisconsin Sys. v. Southworth, $120 \mathrm{~S}$. Ct. 1346 (2000), 11 SETON HAll CONST. L.J. 211 (2000); Jeff Horner, Commentary, Student Fees and First Amendment Concerns, 120 EDUC. L. REP. 911 (1997); Kim Hudson, Comment, To Fee or Not to Fee: The Use of Mandatory Student Activity Fees to Fund Private Organizations that Engage in Political or Ideological Speech or Activity, 30 CUMB. L. REV. 277 (1999-2000); Ryiah Lilith, Current Event, Board of Regents of the University of Wisconsin v. Southworth No. 98-1189, 2000 WL 293217, (U.S. March 22, 2000), 8 AM. U.J. GENDER SOC. POL'Y \& L. 809 (2000); Ralph Mawdsley \& Steven Permuth, Commentary, Mandatory Student Fees and Free Speech, 132 EDUC. L. REP. 265 (1999); Ralph Mawdsley \& Steven Permuth, Commentary: The Supreme Court Upholds Mandatory Student Fees, 145 EDUC. L. REP. 865 (2000); Meredith R. Miller, Comment, Southworth v. Grebe: The Conservative Utilization of "Negative" First Amendment Rights to Attack Diversity of Thought at Public Universities, 65 BROOK. L. REV. 529 (1999); Monte Arthur Mills, Note, The Student, the First Amendment, and the Mandatory Fee, 85 IowA L. REV. 387 (1999); Michael R. O'Neill, California Supreme Court Survey: August 1992 - September 1993, Smith v. Regents of the University of California, 21 PEPP. L. REV. 287 (1993); Kelly Kathleen Ryan, Note, The Cost of Free Speech: First Amendment Limitations of Student Activity Funds - Southworth v. Grebe, 83 MARQ. L. REV. 707 (2000); Christine Theroux, Note, Assessing the Constitutionality of Mandatory Student Activity Fee Systems: All Students Benefit, 33 CONN. L. REV. 691 (2001); Kari Thoe, Note, A Learning Experience: Discovering the Balance Between Fees-Funded Public Fora and Compelled-Speech Rights at American Universities, 82 MiNN. L. REV. 1425 (1998); Scott L. Walker, Note, I'll Speak for 
Lehnert test to the question. ${ }^{76}$ The Supreme Court, however, rejected the Lehnert standard - or any other germaneness test - as applied to student activity fees. The Court argued, first, that the germaneness standard was too vague to be of much use, as evidenced by the divergent opinions on the germaneness of union expenditures in Lehnert. ${ }^{77}$ Second, the Court maintained that it was particularly inappropriate for courts to determine what is germane to the mission of a university because such determinations involve imposing limitations "contrary to the very goal the University seeks to pursue., ${ }^{\prime 78}$ Instead of the three-part Lehnert test, given that the university had a legitimate interest in funding student activities, "[t]he proper measure, and the principal standard of protection for objecting students .... is the requirement of viewpoint neutrality in the allocation of funding support. ${ }^{\prime 79}$

While Kennedy's majority opinion in Southworth is clear as to the reason for the Court's departure from the Lehnert test, it gives little or no guidance as to whether or when courts should apply the viewpointneutrality test in the future. There are three possible readings. The narrowest is that the Southworth test applies only to some subset of

Myself: Compulsory Speech and the Use of Student Fees at State Universities, 52 RUTGERS L. REV. 341 (1999); Robert L. Waring, Comment, Talk Is Not Cheap: Funded Student Speech at Public Universities on Trial, 29 U.S.F. L. REV. 541 (1995); Matthew I. Weinstein, Note, I'm Paying for That? - Assessing the Constitutionality of Mandating Student Activity Fees to Support Objectionable Political and Ideological Activities at Public Universities in Southworth v. Grebe, 44 VILL. L. REV. 257 (1999); Walter James White, Comment, Exploring the Constitutionality of Subsidizing Political Speech with Mandatory Student Activity Fees: Board of Regents of the University of Wisconsin System v. Southworth, 69 MIss. L.J. 1221 (2000); Carolyn Wiggin, Note, A Funny Thing Happens When You Pay for a Forum: Mandatory Student Fees to Support Political Speech at Public Universities, 103 YALE L.J. 2009 (1994). In addition to student notes, see Robert M. O'Neil, Student Fees and Student Rights: Evolving Constitutional Principles, 25 J.C. \& U.L. 569 (1999); Kevin F. O'Shea, First Amendment Cases in Higher Education, 26 J.C. \& U.L. 193 (1999); Roy Whitehead, Jr. \& Walter Block, Mandatory Student Fees: Forcing Some to Pay for the Free Speech of Others, 20 WHITTIER L. REV. 759 (1999).

76 Southworth v. Grebe, 151 F.3d 717, 724-33 (7th Cir. 1998).

7 Southworth, 529 U.S. at 232. For a description of the varying opinions in Lehnert, see infra pp. 1091-09.

78 Id. at 232.

79 Id. at 233; see also id. at 230 ("We decide that the viewpoint neutrality requirement of the University program is in general sufficient to protect the rights of the objecting students.").

The test is taken from the Court's public-forum cases, particularly Rosenberger $v$. Rector \& Visitors of University of Virginia, 515 U.S. 819 (1995) (cited at Southworth, 529 U.S. at 233), which held that a state university's student-activities program created a public forum and therefore must be administered in a viewpoint-neutral fashion to protect the rights of potentially excluded groups. See also Southworth, 529 U.S. at 229-30 (discussing Lamb's Chapel v. Ctr. Moriches Union Free Sch. Dist., 508 U.S. 384 (1993); Widmar v. Vincent, 454 U.S. $263(1981)$ ). 
compelled subsidization cases. The opinion's emphasis on the undesirability of judicial decisions as to what is germane in a university setting might suggest, for instance, that the viewpoint-neutrality test applies only where it is difficult or inappropriate for a court to adjudge germaneness. Along these lines, Leslie Gielow Jacobs has suggested that the Southworth test should apply only where the purpose of the program at issue is "to create a public forum for speech and debate," while the Lehnert test still governs cases where "the government create[s] an organization to serve a primarily nonspeech function. ${ }^{180}$

But if viewpoint neutrality provides enough First Amendment protection in some contexts, why it is it not sufficient in others? That is, if dissenters' rights were not violated by the viewpoint-neutral disbursements challenged in Southworth, the same should be true of other species of viewpoint-neutral disbursements - whether or not germaneness can be adjudged or even if the program serves "a primarily nonspeech function." ${ }^{81}$ Thus a second, more plausible reading is that Southworth provides an independently sufficient criterion for constitutional validity: so long as mandatory payments go to a legitimate governmental program and are distributed in a viewpointneutral manner, they do not violate dissenters' right against compelled subsidization, whether or not they pass the Lehnert test.

But one cannot ignore the fact that Southworth also criticizes the germaneness criterion as being too vague to be of any use. This, combined with the fact that neither Wileman nor United Foods expressly employed the Lehnert test, suggests a third reading: the Supreme Court is in the process of abandoning the Lehnert test or any other germaneness standard. But if this is the case, it is difficult to know what will take Lehnert's place. So far, the Court has not articulated any new test general enough to decide the variety of cases that have come before it, not to mention the other contexts where the doctrine might apply. ${ }^{82}$

${ }^{80}$ Jacobs, supra note 9 , at 443-44.

81 In fact, when Jacobs attempts to explain why constitutional scrutiny was appropriate in the union and integrated bar cases, she recurs to the potential "skewing of the marketplace of ideas," a mode of argument that a broader reading of Southworth's viewpoint neutrality test captures. Id. at 443; see infra pp. 145-46.

${ }_{82}$ Wasserman faults Southworth's viewpoint-neutrality test as opening the floodgates to as-applied challenges to legitimate government sponsored public forms. Wasserman, supra note 23, at 217-19, 228-31. His argument consists of two parts. First, because a requirement of mere facial neutrality could be easily skirted, the Southworth test must look to the actual application of the program, from which it follows that "a single viewpoint-discriminatory decision, even one made in disregard for the plain, viewpoint-neutral language of the program regulations, is sufficient to render the program viewpoint-discriminatory and to trigger the objector's right." Id. at 217. Second, because 
Even without a single, generally applicable test for when compelled subsidization violates the First Amendment, the Court might have provided some per se rules for specific categories of expenditures. Over the years, two viable candidates for such rules have emerged: expenditures for political and ideological activities and expenditures for commercial advertising. But - and this is yet another weakness of the current doctrine - the Court has failed to settle on a rule for either.

The decisions leading up to and including Lehnert might be read to stand at least for the proposition that the compelled subsidization of political and ideological speech is, as such, impermissible. Abood and Keller suggested that in the contexts of the union shop and integrated bar, political or ideological expenditures were per se unconstitutional. Lehnert, the next case to consider such expenditures, allowed certain nonpolitical union outlays, but found that each of the challenged political expenditures failed its three-part test. And, in fact, the Court has never found political or ideological expenditures germane to a legitimate purpose ${ }^{83}$ and has said that such uses pose a particularly heavy burden on dissenters' freedom of expression. ${ }^{84}$

the right against compelled subsidization adheres in every payer, Southworth gives standing to anyone required to pay for the public forum, whereas under the public forum doctrine only those excluded have standing. Id. at 218-19, 229-30. He concludes:

The reliance on viewpoint neutrality in evaluating objecting payers' rights produces the perverse result of an overall decrease in the amount of speech, [if] government makes a single improper viewpoint-discriminatory denial of access, it now must refund some portion of the collected funds to any objecting payer or payers ... By contrast, the ordinary remedy where a speaker unconstitutionally is denied access to a public forum is to require government to admit that speaker to the forum; this broadens access and increases the sum total of expression facilitated by the forum and available in the marketplace.

Id. at 230. But damages for a successful compelled subsidization challenge are relatively small - a refund of a portion of the exacted funds in proportion that the prohibited expenditures bear to total expenditures. See Abood v. Detroit Bd. of Educ., 431 U.S. 209, 237-42 (1977). As a practical matter, it seems unlikely that this amount will be enough either to over-incentivize litigation or to undermine legitimate expressive programs.

83 See Ferris Faculty Ass'n v. Lehnert, 500 U.S. 507, 527, 528-29 (1991); Keller v. State Bar of Cal., 496 U.S. 1, 14 (1990); Chi. Teachers Union, Local No. 1 v. Hudson, 475 U.S. 292, 294 (1986); Abood, 431 U.S. at 235; Bhd. of Ry. \& S.S. Clerks, v. Allen, 373 U.S. 113, 121 (1963); Int'l Ass'n of Machinists v. Street, 367 U.S. 740, 768 (1961). But see Lehnert, 500 U.S. at 535-37 (Marshall, J., dissenting) (arguing that union lobbying activities are germane to collective bargaining); Street, 367 U.S. at 811 (Frankfurter, J., dissenting) (arguing "the practical necessity for unions to participate in what as a matter of analytical fragmentation may be called political activities").

${ }_{84}$ See Lehnert, 500 U.S. at 522 ("Where the subject of compelled speech [sic] is the discussion of governmental affairs, which is at the core of our First Amendment freedoms, the burden upon dissenters' rights extends far beyond the acceptance of the agency shop 
Southworth, however, forecloses any per se rule. The student fees at issue in that case unquestionably went to pay for the political and ideological activities of student organizations, ${ }^{85}$ yet the Court held that so long as the funds were distributed in a viewpoint-neutral manner, dissenting students' First Amendment rights were adequately protected. Now, one might want to distinguish Southworth as applying a different test than Lehnert and other cases. But once one allows that the compelled subsidization of political and ideological activities can pass the Southworth test, there is much less reason to assume that they must fail a germaneness, or any other, standard. And certainly after Southworth it cannot be argued that such expenditures automatically violate the First Amendment.

The other candidate for a per se rule is mandatory payments for commercial speech. Wileman attempted to establish such a rule, concluding that the compelled subsidization of commercial advertising cannot give rise to a crisis of conscience and, as a result, cannot violate the First Amendment. ${ }^{86}$ In fact, Wileman suggests that only "political or ideological disagreement with the content of a message" can meet the crisis-of-consciousness test, ${ }^{87}$ from which would follow a per se rule covering all nonpolitical and non-ideological activities. United Foods, however, rejected such a rule even for commercial speech. According to United Foods, Wileman's crisis-of-conscience test is unprincipled and

and is constitutionally impermissible." (citations omitted)).

${ }^{85}$ The student organizations to which dissenting students objected included the International Socialist Organization, the College Democrats, the College Republicans, a student environmental group, a community legal office and the Wisconsin Student Public Interest Research Group. Southworth, 529 U.S. at 223. The plaintiffs alleged, and the university admitted, that those organizations engaged in "political and ideological expression." Id. at 224, 227.

${ }_{86}$ Prior to Wileman, the Court's rulings concerning nonpolitical, non-ideological expenditures suggested that there was no per se rule for that category. Ellis, the first case to consider nonpolitical expenditures, held that some union expenditures for nonpolitical, non-ideological activities (organizing efforts and litigation not related to the bargaining unit in question) were not germane to collective bargaining, but that others (conventions and union publications) were both germane and sufficiently supported by the government's interest to pass First Amendment scrutiny. Time, Inc. v. Firestone, 424 U.S. 448, 448-51 (1976). Lehnert, applying a somewhat more stringent test, found constitutional all of the nonpolitical, non-ideological expenditures that dissenting employees challenged (litigation supporting the collective bargaining efforts of other bargaining units, internal nonpolitical publications, support of parent organizations, and expenses incident to strike preparation). Lehnert, 500 U.S. at 527-32. Together, these opinions suggest that expenditures for nonpolitical, non-ideological speech must be evaluated on a case-by-case basis, applying the general standards governing compelled subsidization.

${ }^{87}$ Glickman v. Wileman Bros. \& Elliot, 521 U.S. 457, 472 (1997). 
dissenting payers' mere disagreement with the subsidized speech is enough to trigger First Amendment scrutiny. ${ }^{88}$ At the very least, this means that the commercial character of subsidized expression cannot exempt a program from scrutiny. And this reasoning might even be extended to argue against any per se rule for political and ideological expenditures. If there is no principled distinction between the First Amendment harm created by political or ideological expenditures and that created by nonpolitical, non-ideological speech, ${ }^{89}$ and if the compelled subsidization of some non-ideological speech is permissible (see Ellis, Lehnert, and Wileman), then so might the compelled subsidization of some political and ideological speech. Given the sharp divergence between Wileman and United Foods, the status of the compelled subsidization of commercial expression remains unclear, as does the status of expenditures for nonpolitical, non-ideological speech in general.

A final difficulty with the current state of the doctrine is the unprincipled character of the United Foods decision. In order to avoid overruling Wileman, Kennedy's majority opinion distinguishes it based on the idea that there is a greater First Amendment harm where compelled payments fund a purely expressive program than where they fund a program that has non-expressive components. ${ }^{90}$ This claim also stands behind the ruling in the case - because the Mushroom Council engaged primarily in expressive activities, the program violated dissenting industry members' First Amendment right against compelled subsidization. But, as Breyer pointed out in dissent, this approach is problematic both in principle and in its practical consequences. As a matter of principle, it is perverse to hold that the more heavily regulated an industry is, the less First Amendment protection its members have. ${ }^{91}$

88 United States v. United Foods, Inc., 533 U.S. 405, 411 (2001).

${ }^{89}$ Id. at 410-11 ("The subject matter of the speech may be of interest to but a small segment of the population; yet those whose business and livelihood depend in some way upon the product involved no doubt deem First Amendment protection to be just as important for them as it is for other discrete, little noticed groups in a society which values the freedom resulting from speech in all its diverse parts . . First Amendment values are at serious risk if the government can compel a particular citizen, or a discrete group of citizens, to pay special subsidies for speech on the side that it favors; and there is no apparent principle which distinguishes out of hand minor debates about whether a branded mushroom is better than just any mushroom.").

90 Id. at 411-12.

91 Id. at 422 (Breyer, J., dissenting) ("Compared with traditional 'command and control,' price, or output regulation, [the challenged] regulation - which relies upon selfregulation through industry trade associations and upon the dissemination of information - is more consistent, not less consistent, with producer choice. It is difficult to see why a 
As a practical matter, the distinction gives regulators who want to use compelled fees to pay for commercial advertisement an incentive to increase the level of regulation, to add non-expressive components (price or output controls, grading, certification, and so forth) in order to avoid the holding of United Foods. ${ }^{92}$ More fundamentally, the majority in United Foods gives no reason why this distinction should make a difference in the outcome of compelled subsidization cases. The distinction is not connected to the machinery of First Amendment analysis and, as such, is untenable. ${ }^{93}$

The current confusion in the doctrine can be summarized as follows. In 1991, Lehnert provided a seemingly clear test - challenged expenditures must be germane to a vital governmental interest and not significantly add to the burden on dissenters' free speech interests inherent in the program. In practice, however, the Lehnert standard is difficult to apply, because the Court has specified neither how "germane" an expenditure must be nor what free speech interests payments burden. Nine years later, Southworth introduced a fundamentally different standard - compelled payments for the expressive activities of others do not violate dissenters' First Amendment rights so long as the state has a legitimate purpose in imposing the payments and funds are distributed in a viewpoint-neutral manner. But Southworth leaves it unclear whether its viewpoint-neutrality test is meant to apply only to some cases, to serve as an independent test for constitutionality, or to be the first step towards replacing the unworkable Lehnert standard. Nor do Wileman and United Foods provide any indication of the continuing relevance of the Lehnert test or its predecessors. Instead, both introduce additional considerations whether the disputed activities might cause a crisis of conscience and whether compelled payments also fund non-expressive activities without clarifying how they fit in with any general standard or should

Constitution that seeks to protect individual freedom would consider the absence of 'heavy regulation' to amount to a special determinative reason for refusing to permit this less intrusive program." (citation omitted)).

${ }_{92}$ Id. at 429 (arguing that Court's decision "creates an incentive to increase the Government's involvement in any information-based regulatory program.").

${ }_{93}$ With respect to commercial speech, the Supreme Court has held that "the State's power to regulate commercial transactions justifies its concomitant power to regulate commercial speech that is "linked inextricably' to those transactions." 44 Liquormart, Inc. v. Rhode Island, 517 U.S. 484, 499 (1996) (quoting Friedman v. Rogers, 440 U.S. 1, 10 (1979)). But United Foods does not suggest that there must be an inextricable link between the generic industry advertising and the requisite non-expressive components of the program. And there does not seem to have been such a link in the program at issue in Wileman. 
be reconciled with each other. ${ }^{94}$ Nor has the Court adhered to any per se rules about certain categories of expenditures. Political or ideological speech at one time looked as if it might always violate the First Amendment rights of dissenting payers, but cannot be the basis for a per se rule after Southworth. And while Wileman suggested that commercial speech could never give rise to a First Amendment problem, the Court in United Foods rejected such a rule only four years later. Lastly, it is difficult to know what to make of the United Foods emphasis on whether compelled subsidization is part of a broader regulatory program with non-expressive elements.

\section{PROBLEMS IN THEORY: THE COURT'S FAILURE TO EXPLAIN THE DOCTRINE}

Many of the practical problems with the doctrine can be traced back to the Supreme Court's failure to settle on a coherent account of why the compelled subsidization of the speech of others implicates the First Amendment. This part examines two separate arguments that justices have used to explain the First Amendment right not to subsidize, one based on dissenters' freedom of belief and the other on freedom of expression. Both posit harms to the First Amendment rights of individual payers. Neither is satisfactory. ${ }^{95}$ Part III proposes an alternative account of the right not to subsidize, according to which compelled subsidization raises First Amendment issues not because of a harm to individual dissenters, but because of the risk of improper governmental interference in public political discourse.

It is useful to approach the two claimed harms to individual dissenters by way of the now well-established and better-understood First Amendment right against compelled speech - one's right not to be forced to express a message oneself, as opposed to paying for the message of another. The Supreme Court's early compelled speech decisions reflected the idea that compelled speech violates dissenters' freedom of belief. Later decisions have focused on the effects of

${ }^{94}$ Lawrence Tribe has made a similar point about Wileman and Southworth, which, he argues, have been left "to drift awhile beyond the broad current otherwise running through the cases, until later decisions hopefully steer both precedents into the mainstream." Lawrence H. Tribe, Disentangling Symmetries: Speech, Association, Parenthood, 28 PEPP. L. REV. 641, 647 (2001). Presumably Tribe would consider the result in United Foods to be a step back in the correct direction, as he successfully represented the plaintiffs before the Supreme Court in that case. Id. at 646 n.36.

${ }_{95}$ For a similar thesis, supported by somewhat different arguments, see Cantor, supra note 23, at 14-29. It is unfortunate that Cantor's thoughtful early analysis of the issues involved in compelled subsidization has largely been lost on the courts. 
compelled speech on dissenters' expressive capacities. A number of commentators have suggested that compelled subsidization is merely a species of compelled speech. ${ }^{96}$ The argument in this part is that the compelled subsidization of the speech of others causes individual dissenters none of the First Amendment harms caused by compelled speech. Nor has the Court provided an alternative account of the First Amendment harm, leaving the compelled subsidization doctrine essentially adrift.

\section{A. Does Compelled Subsidization Violate Dissenters' Freedom of Belief?}

When describing the First Amendment right against compelled subsidization, the Court and individual justices have repeatedly invoked Thomas Jefferson's statements that "to compel a man to furnish contributions of money for the propagation of opinions which he disbelieves is sinful and tyrannical." ${ }^{\prime 97}$ Justice Stevens's Wileman opinion explained the freedom-of-belief argument as follows:

[Clompelled contributions for political purposes unrelated to collective bargaining implicated First Amendment interests because they interfere with the values lying at the "heart of the First Amendment ... the notion that an individual should be free to believe as he will, and that in a free society one's beliefs should be shaped by his mind and his conscience rather than coerced by the State." ${ }^{\prime 98}$

* See Greene, supra note 23; Kamenshine, supra note 23. Jacobs also assimilates the compelled speech and compelled subsidization doctrines, though Jacobs doesn't explain the one in terms of the other, but attempts to reform both together. Jacobs, supra note 23; see also Wasserman, supra note 23, at 169-90 (treating compelled subsidization and compelled speech as subcategories of "compelled expression"); id. at 205-06 ("The right at issue [in compelled subsidization] is to refrain from speaking and the sole point is that an individual should not be forced to support private speech.").

" Jefferson, supra note 10, at xvii, quoted in Keller v. State Bar of Cal., 496 U.S. 1, 10 (1990); Chi. Teachers Union v. Hudson, 475 U.S. 292, 306 n.15 (1986); Abood v. Detroit Bd. of Educ., 431 U.S. 209, 235 n.31 (1977); Int'l Ass'n of Machinists v. Street, 367 U.S. 740, 779 n.4 (1961) (Douglas, J., concurring); id. at 790 (Black, J., dissenting).

Another common quotation is Madison's observation that "the same authority which can force a citizen to contribute three pence only of his property for the support of any one establishment, may force him to conform to any other establishment in all cases whatsoever." II James Madison, Memorial and Remonstrance Against Religious Assessments, in WRITINGS OF JAMES MADISON 186 (Gaillard Hunt ed., 1901), quoted in Hudson, 475 U.S. at 306 n.15; Abood, 431 U.S. at 235 n.31; Street, 367 U.S. at 779 n.4 (Douglas, J., concurring); id. at 790 (Black, J., dissenting).

${ }_{98}$ Glickman v. Wileman Bros. \& Elliot, 521 U.S. 457, 472 (1997) (quoting Abood, 431 U.S. at 234-35); see also id. at 471 ("Abood merely recognized a First Amendment interest in not 
Compelled subsidization supposedly interferes with freedom of belief because it forces dissenting payers to act in a way contrary to their consciences. But on closer examination, it is impossible to see how compelled payments - even when used for speech - present a distinctively First Amendment harm to dissenters' freedom of belief. To see why this is so, it is helpful to begin with the threat that compelled speech poses to freedom of belief.

It is possible to frame matters so that it is not obvious why requiring someone even to voice certain words - much less requiring her to pay for someone else to voice those words - interferes with her freedom of belief. We all know that what a person says need not correspond to what she believes, especially when she is forced to say it. Think of the Hollywood prisoner of war, forced to state his allegiance to the enemy, but in his heart remaining true to his own country. Or Huck Finn, dutifully reciting his prayers at the Widow Douglas's house, while secretly questioning the coherence of her faith.

Moreover, compelled speech is hardly the only way that the government requires people to act contrary to their beliefs. Catholic charities may be required to pay for insurance that covers contraceptives. ${ }^{99}$ Tax laws demand that everyone earning more than a specified amount pay income tax, regardless of whether they agree with the government programs funded by their tax dollars. ${ }^{100}$ More broadly,

being compelled to contribute to an organization whose expressive activities conflict with one's 'freedom of belief."'); Abood, 431 U.S. at 235-36 ("The fact that the appellants are compelled to make, rather than prohibited from making, contributions for political purposes works no less an infringement on their constitutional rights. For at the heart of the First Amendment is the notion that an individual should be free to believe as he will, and that in a free society one's beliefs should be shaped by his mind and his conscience rather than coerced by the state."); Lathrop v. Donahue, 367 U.S. 820, 874 (1961) (Black, J., dissenting) ("At stake here is the interest of the individual lawyers of Wisconsin in having full freedom to think their own thoughts, speak their own minds, support their own causes and wholeheartedly fight whatever they are against."); Street, 367 U.S. at 776 (Douglas, J., concurring) (stating that compelled subsidization requires dissenters "to surrender . . . matters of conscience, belief or expression"); $i d$. at 788 (Black, J., dissenting) (concluding that compelled subsidization violates individual dissenters" rights to "think, speak, write and worship as they wish").

99 See Catholic Charities of Sacramento, Inc. v. Superior Court, 85 P.3d 67, 95 (Cal. 2004); Inimai M. Chettiar, Comment, Contraceptive Coverage Laws: Eliminating Gender Discrimination or Infringing on Religious Liberties, 69 U. CHI. L. REV. 1867 (2002).

${ }_{100}$ Powell, concurring in Abood, suggested that "[c]ompelled support of a private association is fundamentally different from compelled support of government" because "government is representative of the people" and "[t]he same cannot be said of a union, which is representative only of one segment of the population, with certain common interests." Abood, 431 U.S. at 259 n.13 (Powell, J., concurring). As Tribe points out, this argument is unsatisfactory. "[S]ince the authority of the public employees' union to 
virtually every coercive law - from child welfare laws to workforce safety regulations to speed limits - is open to the objection that it will force some people to act against what they believe best. If compelled speech involves a special First Amendment harm to freedom of belief, it must be distinguished from these other forms of government coercion. We need a fuller account of just how compelled speech, and then also of how the compelled subsidization of the speech of others, threatens freedom of belief.

The early compelled speech cases suggest two possible answers to the first question: compelled speech threatens freedom of belief, first, when it is used as a tool of indoctrination and, second, when it interferes with the free exercise of belief. The first Supreme Court decision to recognize a First Amendment right against compelled speech, West Virginia $v$. Barnette, emphasized indoctrination. ${ }^{101}$ West Virginia had required school children to salute the flag, else face expulsion. ${ }^{102}$ The plaintiffs were Jehovah's Witnesses and considered saluting the flag contrary to their religious duties. ${ }^{103}$ The majority posed the question as whether state indoctrination was consistent with the Constitution. ${ }^{104}$ With National Socialism looming in the background, the Court held:

Authority here is to be controlled by public opinion, not public opinion by authority. . . If there is any fixed star in our constitutional constellation, it is that no official, high or petty, can prescribe what shall be orthodox in politics, nationalism, religion, or other matters of opinion or force citizens to confess by word or act their faith therein. ${ }^{105}$

When the state compels speech in the service of indoctrination, it threatens the citizenry's freedom of belief and infringes on its First Amendment rights.

The other way compelled speech can interfere with freedom of belief is when it prevents a person from exercising or acting on her beliefs in

compel support is derived from the legislature, the cases seem hard to distinguish on any private-public ground." LAWRENCE H. TRIBE, AMERICAN CONSTITUTIONAL LAW 808 n.14 (2d ed. 1988). Nor can Powell's distinction explain the outcome in Southworth, in which funds again went to private groups. Bd. of Regents v. Southworth, 529 U.S. 217 (2000). Finally, Powell's argument does not isolate what is special about the compelled subsidization of private speech - why it is different from, say, the harm to the committed Catholic of being required to pay into a health insurance plan that pays for birth control.

101 W. Va. State Bd. of Educ. v. Barnette, 319 U.S. 624 (1943).

102 Id. at 626-29.

103 Id. at 629.

104 Id. at $640-42$.

105 Id. 
some important way. This aspect was also present in Barnette, where the plaintiffs argued that saluting the flag interfered with their commitment to Exodus 20:4-5 ("Thou shalt not make unto thee any graven image . . . nor bow down thyself to them nor serve them."). ${ }^{106}$ Interference with freedom of belief was also central to the decision in Wooley $v$. Maynard, ${ }^{107}$ the Court's next significant compelled speech case. Wooley considered a Jehovah's Witness's objection to New Hampshire's requirement that his license plate display the motto "Live Free or Die," which he found "morally, ethically, religiously and politically abhorrent." ${ }^{108}$ New Hampshire's license plate was clearly not an attempt to indoctrinate (a driver rarely sees her own license plate). Nonetheless, the Court found the requirement unconstitutional: "The First Amendment protects the right of individuals to hold a point of view different from the majority and to refuse to foster, in the way New Hampshire commands, an idea they find morally objectionable."109 The interference with freedom of belief here was not in the form of indoctrination, but in preventing the plaintiff from acting in accordance with his most deeply held convictions, which in this case required that he not display the state motto.

So, these are two ways the Court has identified in which compelled speech can interfere with the freedom of belief. The next question is whether compelled subsidization of speech interferes with belief in either of these ways. (If there is another sort of interference with dissenters' freedom of belief, proponents of the doctrines have yet to identify it.)

Indoctrination is the simpler case. Compelled speech can serve as a tool of indoctrination because requiring a person - especially a schoolchild - to repeat a message can eventually cause her to believe it. Because compelled subsidization does not require dissenters to repeat any message, it is a poor tool for indoctrination. As Justice Harlan noted in Lathrop, there can be no "desire to induce belief or conviction by the device of forcing a person to identify himself with the expression of such views ... where the connection between the payment of an individual's dues and the views to which he objects is factually so remote."110

If there is a coherent argument that compelled subsidization violates dissenters' freedom of belief, it is that it interferes with their ability to exercise, realize, or act on their beliefs, in the way Wooley emphasized.

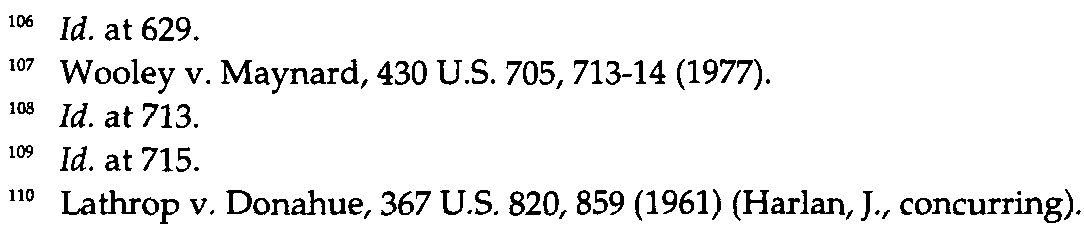


The argument must be that by requiring someone to pay for a message with which she disagrees, compelled subsidization requires her to act contrary to her own beliefs in a way that violates the protections of the First Amendment. But, as noted above, one might object to virtually every form of state compulsion on similar grounds. We still must identify some uniquely relevant harm caused by forcing someone to speak or to pay for the speech of others - a harm distinct from the interference with belief that potentially accompanies all state compulsion.

One can read Wileman's "crisis of conscience" test as an attempt to establish such a limiting principle. ${ }^{111}$ But only four years later, United Foods reversed course and rejected this test as unprincipled. ${ }^{112}$ And it is true that the crisis-of-conscience line is not so bright as one might hope. But the real problem with Wileman's proposed standard is not that it is vague, but that it does not indicate what is special about the compelled subsidization of speech. Even if we allow that being required to support a message one disagrees with can create a crisis of conscience, so might being required to pay for a non-expressive activity or, for that matter, to engage in or refrain from other non-expressive acts. This is not a principle that distinguishes a special threat posed by the compelled subsidization of speech.

One clear constitutional boundary is the line around cases where dissenters' religious beliefs are at stake. If the free speech clause does not draw the line here, the free exercise clause does. It is telling that the plaintiffs both in Barnette and in Wooley were Jehovah's Witnesses and objected to the required speech acts on religious grounds. This is also the point of Jefferson's statement, often quoted out of context and in support of the compelled subsidization doctrine, that "to compel a man to furnish contributions of money for the propagation of opinions which he disbelieves is sinful and tyrannical." ${ }^{113}$ The sentence comes from Jefferson's Statute of Virginia for Religious Freedom, and concerns only the compelled subsidization of religious activities, gesturing toward the link between the anti-establishment and free exercise principles. When the state compels a person to do something contrary to her religious beliefs,

"11 Glickman v. Wileman Bros. \& Elliot, 521'U.S. 457, 472 (1997).

112 United States v. United Foods, Inc., 533 U.S. 405, 411 (2001).

${ }^{113}$ Jefferson, supra note 10, at xvii. For compelled subsidization decisions that appeal to Jefferson's statement, and a similar one from Madison, both out of context, see Chi. Teachers Union v. Hudson, 475 U.S. 292, 306 n.15 (1986); Abood v. Detroit Bd. of Educ., 431 U.S. 209, 235 n.31 (1977); Int'l Ass'n of Machinists v. Street, 367 U.S. 740, 779 n.4 (1961) (Douglas, J., concurring); id. at 790 (Black, J., dissenting). 
regardless of whether the requirement is that she speak, pay money for speech, or engage in some conduct with no relation to speech, the First Amendment is clearly implicated and the state action is subject to constitutional scrutiny.

Yet, this is insufficient to ground either the right against compelled speech or the right against the compelled subsidization of the speech of others. Each requires an argument both narrower and broader than the free exercise principle. The argument must be narrower because these rights are supposed to apply only to compulsion to engage in or to fund expressive activities, while the free exercise interest extends to any compelled action that goes against one's religious beliefs. It must be broader because these rights are meant to apply also where dissenters' objections are purely secular.

Here is an answer for compelled speech: The requirement that a speaker herself give voice to a message can impinge on her beliefs religious or not - in a distinctive way because it is often central to our most deeply held beliefs that we be able to express them in words. ${ }^{114}$ This is true whether those beliefs are religious, political, moral, or otherwise central to our self-identity. Forcing a person to express a message contrary to such beliefs can thus threaten her ability to control what she tells the world about who she is and what she holds important. The principle here is narrower in the necessary way, for it highlights what is special about speech or expression, and therefore answers the objection that the government requires people to do all sorts of nonexpressive things that they disagree with. It is also broader than the free exercise principle in the right way, for it is not limited to religious dissent from the required message. This is how the First Amendment right

114 Abner Greene emphasizes this sort of harm in his account of the First Amendment's prohibition on compelled speech:

My proposal here is that compelled speech cases ... should be seen as autonomy or personhood cases .... Just as it would be hard to justify a governmental requirement that everyone wear blue on Fridays, or that everyone eat ice cream once a week, so it is hard to justify a governmental requirement that everyone say the pledge of allegiance. The concern in the pledge of allegiance situation, thus, is centered not on the speech involved, but rather on the intrusion on and insult to the person and the weakness of the regulatory need.

Greene, supra note 23, at 481; see also Paul G. Stern, Note, A Pluralistic Reading of the First Amendment and its Relation to Public Discourse, 99 YALE L.J. 925, 935-36 (1990) (arguing that ability to speak freely is essential to freedom of belief because "[s]peaking with others about their rival values and ideals is . . . constitutively linked to the possibility of an individual agent exercising a deliberative choice of how she wants to live"). 
against compelled speech can be grounded in the freedom of belief. ${ }^{115}$

But does this argument, or one like it, carry over to the compelled subsidization of the speech of others? It does not, and for two reasons. First, the compelled act itself - paying a mandatory fee - has too little moral content. The point can be made by way of analogy. We recognize the conscientious objector's right not to carry a gun, but not her right not to pay taxes that fund the military. ${ }^{116}$ One reason for this difference is that we do not consider the act of paying taxes to touch on her beliefs in the same way that military service would. ${ }^{117}$ Similarly, the mere act of paying for an objectionable message interferes less with a dissenter's beliefs than would being forced to express that message herself. Like the taxpaying conscientious objector, she is not required to engage in the very activities she finds objectionable. This distinction is not an a priori moral truth - a radical consequentialist might refuse to recognize any difference between these cases. But ours is not such a morality. The difference between paying for and doing reflects a real difference in our attitudes towards these different categories of compulsion. Among other things, we find that it interferes more with a person's ability to act in accordance with her beliefs when she is required to do something she considers intrinsically wrong than when she is required to underwrite someone else's acts that she believes wrong.

The second reason why compelled subsidization does not interfere with freedom of belief is the semantic gulf between the act of paying and the speech it helps fund. Compelling a person to express a message herself presents a particular sort of threat to her freedom of belief. It threatens her ability to control what she tells the world about who she is and what she holds important - forms of expression that can trigger the First Amendment because they are essential to realizing certain deeply held beliefs. The requirement that a person do no more than pay for a message she disagrees with does not threaten this sort of harm. I touch on a theme here that will be explored at greater length in the next part of this Article, which discusses dissenters' expressive interests. But, the thesis can be stated now: The mere act of paying a mandatory assessment does not identify the payer with the message her payments

115 Whether it explains the Court's compelled speech cases is a question that need not be answered here. It is enough to show that it is a coherent way of thinking about compelled speech as a special threat to freedom of belief.

116 See United States v. Lee, 455 U.S. 252, 260 (1982).

${ }_{117}$ See id. at 263 n.3 (Stevens, J., concurring) (arguing that in instance like tax case, "almost insurmountable burden" should be placed on objector who claims that governmental compulsion conflicts with religious beliefs). 
help fund. No one mistakes that act for an expression of belief. There is no signifier-signified relationship. Consequently, the mere act of paying does not interfere with the dissenter's ability to express her beliefs. While she may object to the requirement that she fund the message, any harm she suffers is not a distinctively First Amendment harm. ${ }^{118}$

The claim that compelled subsidization of the speech of others infringes on dissenters' First Amendment freedom of belief is ultimately untenable. Compelled subsidization is not a tool of indoctrination. Nor does it interfere with dissenters' ability to practice or realize their beliefs in any distinctively First Amendment way. Justice Harlan put the point as follows: "Of course it is disagreeable to see a group, to which one has been required to contribute, decide to spend its money for purposes the contributor opposes. But the Constitution does not protect against the mere play of personal emotions. ${ }^{\prime 119}$ If the compelled subsidization doctrine is grounded in a First Amendment harm to individual dissenters, that harm must be of a different sort.

\section{B. Does Compelled Subsidization Interfere with Dissenters' Freedom of Speech?}

The other argument that the Court and individual justices have put forward in support of the doctrine is that compelled subsidization interferes with dissenters' ability to speak - that it involves the same sort of expressive harm that compelled speech does. The argument goes back to Black's and Douglas's 1961 opinions in International Ass'n of Machinists v. Street and Lathrop v. Donahue, ${ }^{120}$ though it gained

${ }^{118}$ Wasserman, who advocates a freedom-of-belief type argument, argues that the First Amendment harm of compelled subsidization does not turn on a public connection between the funder and the message funded because "[ $t$ he dignitary interest in freedom of conscience rests on an inward focus on the individual's own mind," not "how the reasonable outside world views or understands the message and the individual's connection to it." Wasserman, supra note 23, at 206. But without a semantic nexus, Wasserman cannot explain what is special about the compelled subsidization of speech, as opposed to payments for non-expressive activities. From the point of view of the individual payer, funding non-expressive activities can cause just as much dignitary harm as funding speech. Wasserman does suggest that courts limit the compelled subsidization doctrine to instances where payments fund expression. Id. at 201-02, 207. But he has no principled argument for this restriction, appealing instead to the practical need to cabin the doctrine so as to protect the government's ability to use tax dollars as it will and to the First Amendment interest in increasing the total amount of speech. Id. at 196-200.

119 Lathrop v. Donahue, 367 U.S. 820, 857 (1961) (Harlan, J., concurring).

${ }^{20}$ See Int'l Ass'n of Machinists v. Street, 367 U.S. 740, 788 (1961) (Black, J., dissenting) ("Compelling a man by law to pay his money to elect candidates or advocate laws or doctrines he is against differs only in degree, if at all, from compelling him by law to speak for a candidate, a party, or a cause he is against."); Lathrop, 367 U.S. at 882 (Douglas, J., 
momentum after Buckley $v$. Valeo, ${ }^{121}$ which held inter alia that limitations on campaign contributions "implicate fundamental First Amendment interests." ${ }^{122}$ In its simplest form, the argument goes like this: Buckley established that contributors have an expressive interest in being able to give money to election campaigns and held that the government may no more restrict payments for the speech of others. than it may restrict speech itself. It follows that to compel payments for the speech of others threatens dissenters' freedom of expression just as much as compelling them to speak. In short, compelled subsidization is a species of compelled speech and subject to the same constitutional protections. ${ }^{123}$

Stated so simply, one of the argument's flaws is obvious: Buckley and the campaign finance cases that followed have not provided campaign contributions the same level of First Amendment protection afforded to political speech. Buckley held that, unlike speech, the "quantity of commutation by the contributor does not increase perceptibly with the size of his contribution, since the expression rests solely on the undifferentiated, symbolic act of contributing." ${ }^{124}$ The Court concluded that contributors did not have the same expressive interest in their contributions that speakers have in the words they utter. It therefore upheld contribution limits, though analogous restrictions on how much a speaker could say would clearly be unconstitutional. If Buckley stands for anything, it is that payments for speech, while enjoying some degree of First Amendment protection, are not speech. The state may restrict payments for the speech of others in ways that it is not permitted to

dissenting) (emphasizing "the inroads of an integrated bar on the liberty and freedom of lawyers to espouse such causes as they choose").

121 See Glickman v. Wileman Bros. \& Elliot, 521 U.S. 457, 504 n.1 (1997) (Thomas, J., dissenting); Keller v. State Bar of Cal., 496 U.S. 1, 9-10 (1990); Abood v. Detroit Bd. of Educ., 431 U.S. 209, 234 (1977); id. at 255-56 (Powell, J., concurring). Lehnert also drew the connection between compelled subsidization and compelled speech, though it did not mention Buckley. Lehnert v. Ferris Faculty Ass'n, 500 U.S. 507, 516-17 (1991) (citing Wooley v. Maynard, 430 U.S. 705, 714 (1977)).

122 Buckley v. Valejo, 424 U.S. 1, 23 (1976) (cited in Abood, 431 U.S. at 234). McConnell does not expressly depart from this view, though it does minimize the expressive value of a campaign contribution for the contributor, as opposed to the candidate receiving it. See Lathrop, 367 U.S. at 135 ("Because the communicative value of large contributions inheres mainly in their ability to facilitate the speech of their recipients, we have said that contribution limits impose serious burdens on free speech only if they are so low as to 'preven[t] candidates and political committees from amassing the resources necessary for effective advocacy." (citing Buckley, 424 U.S. at 21)).

123 Accord Wileman, 521 U.S. at 478-87 (Souter, J., dissenting).

124 Buckley, 424 U.S. at 21. But see Nixon v. Shrink, 528 U.S. 377, 414 (2000) (Thomas, J., dissenting) ("In Federal Election Comm'n v. National Conservative Political Action Comm., 470 U.S. 480 ... (1985), we cast aside the argument that a contribution does not represent the constitutionally protected speech of a contributor...."). 
restrict speech itself.

A close reading of Buckley reveals a second, methodological error in the above argument. The Buckley Court reached its conclusion only after closely examining the particular expressive potential of campaign contributions, that is, their semantic content. Whether payment for the speech of others also triggers the protections of the compelled speech doctrine can be decided only by further engaging in this essentially interpretive task, only through a close examination of the particular expressive interests at stake. ${ }^{125}$ There is no simple syllogism from the fact that an activity has some expressive content, and therefore warrants some First Amendment protection, to the conclusion that it deserves the full First Amendment panoply.

Let us therefore return to the basics of compelled speech and how it interferes with dissenters' expressive interests (as opposed to their freedom of belief). While the Supreme Court's early decisions emphasized the ways in which compelled speech can burden freedom of belief, later decisions have emphasized dissenters' ability to speak. Once we have a clear picture of how compelled speech interferes with dissenters' expressive interests, we can then ask whether compelled subsidization causes a similar harm.

Justice Rehnquist's dissent in Wooley $v$. Maynard, and its holding that New Hampshire's license plate requirement was constitutionally impermissible, sharpens the compelled speech question. Rehnquist's argument was that a compulsory license plate motto simply was not speech.

What the Court does not demonstrate is that there is any "speech" or "speaking" in the context of this case. . . . The issue, unconfronted by the Court, is whether appellees, in displaying, as they are required to do, state license tags, the format of which is known to all as having been prescribed by the State, would be considered to be advocating political or ideological views. ${ }^{126}$

125 This more particularized approach can be contrasted with that taken by Jacobs's analysis of the link between the compelled subsidization and campaign contribution limits. Jacobs argues that the First Amendment harm is the same in both contexts - "the marketplace of ideas effect rather than . . . any abstract assessment of the degree of individual autonomy impingement" that brings the First Amendment into play. Jacobs, supra note 9, at 455 . But restrictions on campaign contributions may well entail individual harms (the ability of the contributor to express her support for a candidate in her chosen medium) that compelled subsidization of speech does not.

${ }^{126}$ Wooley, 430 U.S. at 720-21 (Rehnquist, J., dissenting). Abner Greene advocates a similar analysis of whether compelled speech counts as speech at all. Greene, supra note 23, at 473-75. Rehnquist, however, has probably since abandoned this position. See Boy Scouts 
There are two ideas at work here. First, Rehnquist is saying that what matters is whether the dissenter is likely to be identified or associated with the message she is required to carry. Second, he insinuates that so long as it is common knowledge that she is compelled to carry the message, no one will interpret her words as an expression of her opinion. Thus Rehnquist concludes that "[ $t]$ he State has not forced appellees to 'say' anything." ${ }^{127}$ If compelled "speech" is not really speech for First Amendment purposes, then how can it possibly burden the expressive interests protected by the First Amendment?

The Wooley majority did not answer Rehnquist's objection. As discussed above, the majority opinion emphasized the interference with the dissenter's freedom of belief, as opposed to her ability to speak. Consequently, the Court rejected the underlying premise of Rehnquist's argument. ${ }^{128}$ But subsequent compelled speech cases have addressed Rehnquist's challenge and have held that, in most cases, the sina qua non of a First Amendment compelled speech problem is a strong likelihood that the compelled message will be associated with the person required to carry it.

Just three years after Wooley, a majority of the Court agreed with the first premise of Rehnquist's analysis. PruneYard Shopping Center v. Robins concerned a shopping center owner's objection to California's requirement that petitioners be allowed to use the public spaces in the shopping center to gather signatures. ${ }^{129}$ Rehnquist's majority opinion found no First Amendment violation and explained that result as follows:

Most important, the shopping center by choice of its owner is ... a business establishment that is open to the public to come and go as they please. The views expressed by members of the public in passing out pamphlets or seeing signatures for a petition thus will not likely be identified with those of the owner. ${ }^{130}$

of Am. v. Dale, 530 U.S. 640, 653 (2000) ("Dale's presence in the Boy Scouts would, at the very least, force the organization to send a message, both to the youth members and the world, that the Boy Scouts accepts homosexual conduct as a legitimate form of behavior.").

${ }^{127}$ Wooley, 430 U.S. at 720 (Rehnquist, J., dissenting).

${ }_{128}$ Id. at 716-17.

129 PruneYard Shopping Ctr. v. Robins, 447 U.S. 74, 74 (1980).

130 Id. at 87 (emphasis added); see also id. at 99 (Powell, J., concurring) ("[S]peech interests are affected when listeners are likely to identify opinions expressed by members of the public on commercial property as the views of the owner."); Pac. Gas \& Elec. v. Pub. Utils. Comm'n, 475 U.S. 1, 12 (1986) ("PruneYard ... does not undercut the proposition that forced associations that burden protected speech are impermissible."). Chief Justice Rehnquist also found it significant that no specific message was dictated and that the 
PruneYard, however, drops the second idea in Rehnquist's Wooley dissent - the idea that a compelled message will never be identified with its carrier. It is replaced by an empirical inquiry into context and meaning. This inquiry asks whether this is the sort of situation in which observers are likely to identify the message with the person forced to carry it. The case of the shopping center does not meet this test, but other cases might. Thus in a concurring opinion, Justice Powell explained that in a different case, compelled identification with a message might interfere with a dissenter's expressive interests, because it would put him in a bind: either say nothing, in which case he "has been compelled to affirm someone else's belief," or disavow the compelled message, in which case he "has been compelled to speak when [he] would prefer to remain silent." "131

In its two major compelled-speech cases since PruneYard, the Supreme Court has maintained this approach. ${ }^{132}$ In Pacific Gas and Electric v. Public Utilities Commission of California, the Court held that a requirement that a public utility place the newsletter of a third party in its billing envelope violated the First Amendment. ${ }^{133}$ Powell's plurality opinion follows the logic of PruneYard, but concludes that in the case of a billing envelope, unlike a shopping mall, there is a "forced association with potentially hostile views" that violates the First Amendment right to remain silent. ${ }^{134}$ In Hurley v. Irish-American Gay, Lesbian and Bisexual Group of Boston, a

owner could expressly disavow any connection with the message. PruneYard, 447 U.S. at 87.

131 PruneYard, 447 U.S. at 99 (Powell, J., concurring).

${ }_{132}$ See also Turner Broad. Sys. v. FCC, 512 U.S. 622, 655-56 (1994) (Cable must-carry provisions do not force messages on cable operators, because there is "little risk that cable viewers would assume that the broadcast stations carried on a cable system convey ideas or messages endorsed by the cable operator.").

133 Pac. Gas, 475 U.S. at 20-21 (1986).

134 Id. at 18; see also id. at 15 (requirement "impermissibly requires [the utility] to associate with speech with which [it] may disagree); id. at 20-21 ("the Commission's order impermissibly burdens appellant's First Amendment rights because it forced appellant to associate with the views of other speakers ....").

Justice Burger concurred, agreeing with the relevance of the possible identification of the utility with the message it was required to carry. Id. at 21 (Burger, J., concurring) (identifying "the central question presented by this case" as "the infringement of Pacific's right to be free from forced association with views with which it disagrees").

Chief Justice Rehnquist dissented from Pacific Gas, based in part on his different opinion as to the factual matter of whether consumers were likely to identify the utility with the opinions expressed in the insert. "The plurality argues ... that the right of access also implicates [the utility's] right not to speak or to associate with the speech of others.... The plausibility of any such prediction depends on the perceived ineffectiveness of a disclaimer or the absence of any effective alternative means for consumer groups . . . to communicate to the ratepayers." Id. at 31 (Rehnquist, J., dissenting). 
unanimous Court held that Massachusetts violated the First Amendment rights of private parade organizers by requiring them to allow a group promoting homosexual rights to march in their St. Patrick's Day parade. ${ }^{135}$ The Court again posed the question in terms of whether the speaker was likely to be identified with the message it was required to carry. ${ }^{136}$ It concluded that in "the context of an expressive parade . . each unit's expression is perceived by spectators as part of a whole," and that spectators were therefore likely to identify the group's message with the parade as a whole. ${ }^{138}$

We can now return to the compelled subsidization of the speech of others. Taking Buckley's particularized analysis as a model, the question is whether, or to what extent, the expressive interests at stake in compelled speech - the likely identification of the speaker with the message she is forced to carry - are also in play in the compelled subsidization of the speech of others.

To begin with, let us distinguish the situation where an individual dissenter objects because the speech she is paying for expressly identifies her with its message. Thus a milk producer might object to a generic milk advertisement with the tagline, "Brought to you by America's dairy farmers," or an auto worker to a union ad that concludes, "A message from America's auto workers." If this is the complaint, then it has nothing to do with compelled subsidization. The expressive harm - the forced association with an objectionable message - lies in the false attribution and exists whether or not the dissenter is required to pay for that message. In fact, this is simply another species of compelled speech - different in that the dissenter is not required to carry the message herself, but identical with respect to the nature of the harm. The problem is nicely captured by an appropriate metaphor: the government is putting words in people's mouths.

Putting aside such generic identification with a message, the question is whether compelled payments themselves cause an expressive harm. They do not, because there is no semantic nexus between the act of paying and the message expressed. Buckley was right to recognize that voluntary payments for the speech of others are often interpreted as

135 Hurley v. Irish-American Gay, Lesbian and Bisexual Group of Boston, 515 U.S. 557, 559 (1995).

${ }^{136}$ Id. at 575 .

137 Id. at 577.

${ }^{138}$ Id. at 575 ("GLIB's participation would likely be perceived as having resulted from the Council's customary determination about a unit admitted to the parade, that its message was worthy of presentation and quite possibly of support as well."). 
symbolic acts of support, that they have an (albeit limited) expressive content. But - and this is a version of the second idea implicit in Rehnquist's Wooley dissent - our linguistic community does not interpret the payment of mandatory assessments in the same way. And, because the act of paying is not intrinsically symbolic, there is no chance that compelled subsidization will be mistaken for something it is not, as a newsletter in a billing envelope or a banner in a parade might be. The one simply does not signify the other. The Wileman majority made precisely this point when it rejected the idea of a connection between compelled subsidization and compelled speech.

The use of assessments to pay for advertising does not require respondents to repeat an objectionable message out of their own mouths, require them to use their own property to convey an antagonistic ideological message, force them to respond to a hostile message when they "would prefer to remain silent," or require them to be publicly identified or associated with another's message. Respondents are not required themselves to speak, but are merely required to make contributions for advertising. ${ }^{39}$

There is no danger that dissenting payers will be understood to be espousing the message their payments help fund. Consequently, according to the compelled speech doctrine itself, dissenters have no First Amendment complaint. ${ }^{140}$ Though their payments fund expression, the requirement to pay does not cause them an expressive harm. ${ }^{141}$

139 Glickman v. Wileman Bros. \& Elliot, 521 U.S. 457, 470-71 (1997) (emphasis added, citations omitted); see also Bd. of Regents v. Southworth, 529 U.S. 217, 239-40 (2000) (Souter, J., dissenting) ("In each [of the Court's compelled speech] cases, the government was imposing far more directly and offensively on an objecting individual than collecting the fee that indirectly funds the jumble of other speakers' messages in this case." (citing Hurley, 515 U.S. at 572-74, Wooley v. Maynard, 430 U.S. 705, 707 (1977), and W. Va. St. Bd. of Educ. v. Barnette, 319 U.S. 624, 626-29 (1943)); Lehnert v. Ferris Faculty Ass'n, 500 U.S. 507, 541 (1991) (Marshall, J., concurring in part and dissenting in part) ("Petitioners' expressive capacities have not been conscripted. Rather, petitioners have simply been required to pay a pro rata share of lobbying costs incurred by a union representative, chosen pursuant to majority vote."); Int'l Ass'n of Machinists v. Street, 367 U.S. 740, 806 (1961) (Frankfurter, J., dissenting) ("No one's desire or power to speak his mind is checked or curbed."); Lathrop v. Donahue, 367 U.S. 820, 860 (1961) (Harlan, J., concurring) ("I do not think a . . decision by the representatives of the majority of the bar members to devote some part of the organization's funds to the furtherance of a legislative proposal so identifies the individual payor of dues with the belief expressed that we are in the Barnette realm of 'asserted power to force an American citizen publicly to profess any statement of belief or to engage in any ceremony of assent to one."').

140 PruneYard Shopping Ctr. v. Robins, 447 U.S. 74, 87, 99 (1980).

141 Given that this conclusion rests on an analysis of compelled speech that Justice Rehnquist introduced in Wooley and has never disclaimed (though see supra note 126), it is 
This analysis is consistent with the Supreme Court's broader formulation of the difference between speech and conduct. In Texas $v$. Johnson, the Court held that "[i]n deciding whether particular conduct possesses sufficient communicative elements to bring the First Amendment into play, we have asked whether '[a]n intent to convey a particularized message was present, and [whether] the likelihood was great that the message would be understood by those who viewed it."'142 Rehnquist suggested in his Wooley dissent that compelled speech is unusual because it does not meet the first prong of this test - the speaker does not necessarily want to convey the message and thus the message is not intended in the relevant sense. ${ }^{143}$ Subsequent cases have recognized, however, that some compelled speech still meets the second prong - it can be interpreted as conveying a message - and therefore still triggers First Amendment scrutiny. ${ }^{144}$ Compelled subsidization of the speech of others can satisfy neither prong. It is neither intended as a communicative act nor understood as one. As such, it does not qualify as speech under the Texas $v$. Johnson test. The First Amendment protects the rights of individual dissenters - be it to freedom of belief or to freedom of speech - only to the extent that dissenters intend to say something or will be viewed as doing so. Where neither is the case, there is no First Amendment harm.

difficult to understand why Rehnquist has consistently signed on to opinions identifying the right against compelled subsidization with the right against compelled speech (including Souter's dissent from Wileman). Rehnquist himself, in his dissent from Wooley, anticipated the issues discussed here and perfectly described the lack of an expressive interest at stake in compelled subsidization:

For example, were New Hampshire to erect a multitude of billboards, each proclaiming "Live Free or Die," and tax all citizens for the cost of erection and maintenance, clearly the message would be "fostered" by the individual citizentaxpayer and just as clearly those individuals would be "instruments" in that communication. Certainly, however, that case would not fall within the ambit of Barnette. In that case, as in this, there is no affirmation of belief. For First Amendment principles to be implicated, the State must place the citizen in the position of either apparently, or actually "asserting as true" the message.

Wooley v. Maynard, 430 U.S. 705, 721 (1977) (Rehnquist, J., dissenting).

${ }_{142}$ Texas v. Johnson, 491 U.S. 397, 404 (1989) (quoting Spence v. Washington, 418 U.S. 405, 410-11 (1974)).

143 Wooley, 430 U.S. at 720-21 (Rehnquist, J., dissenting).

14 Hurley, 515 U.S. at 575, 577; Pac. Gas \& Elec. Co. v. Pub. Utils. Comm'n, 475 U.S. 1, $15,18,20-21$. 


\section{A First Amendment Harm to Individual Dissenters?}

We have yet to be provided with an adequate description of a First Amendment harm to individuals who are forced to subsidize the speech of others. Recourse to freedom of belief fails, first, because the mere act of paying for the actions of others is too morally thin to support the claim that it significantly interferes with dissenters' ability to act on their beliefs and, second, because there is no principled explanation of why the compelled subsidization of speech interferes with dissenters' beliefs more than payments for other activities. The appeal to freedom of expression fails because no one is likely to identify dissenters with the views their payments help fund. As a matter of logic, this does not prove that compelled subsidization causes individual dissenters no First Amendment harm. It does, however, show that we have yet to receive a convincing account of such a harm. The burden is on those who say it exists to come forward with an explanation of where it lies. ${ }^{145}$

\section{An Alternative AcCount OF the FirSt AMENDMENT Right Not to SUBSIDIZE}

Without a coherent account of precisely how compelled subsidization threatens First Amendment interests, the outcomes of cases have depended on the competing intuitions of the justices deciding them,

145 Lawrence Tribe has argued that both the compelled speech and the compelled subsidization cases should be understood as resting on

a right not to be used or commandeered to do the state's ideological bidding by having to mouth, convey, embody or sponsor a message, especially the state's message, with one's voice or body or resources, on one's personal possessions, through the composition of the associations one joins or forms, or in their selection of teachers, exemplars, and leaders.

Tribe, supra note 94 , at 645 . But when he attempts to explain the basis of this First Amendment anti-commandeering principle, Tribe returns to the idea that it is the message itself, not the fact that it is funded through compelled subsidization, that is the problem:

In contrast, any legitimate goals the state seeks to achieve by using individuals or associations to convey or endorse its views are likely to be achievable by the state speaking with its own voice, at the expense of all taxpayers rather than just those few who are singled out to bear the burden as serving as the state's megaphone.

Id. (emphasis added). The suggestion seems to be that the fact that all taxpayers are not asked to pay for the message is evidence that the message itself is problematic - perhaps because it is too unpopular or controversial. (Tribe doesn't explain what he means by "legitimate.") But this evidentiary observation should not be mistaken for a constitutional principle. Tribe's argument suggests that the real problem is not that the cost is born by the few, but that the message expressed is not a permissible one. If this is the case, why not simply focus on the constitutional legitimacy of the message? 
rather than on a general rule. Thus we find one test for unions and state bars (the three-part Lehnert test), another for commercial advertising (most recently germaneness to a non-expressive program), and still a third for student fees (legitimate purpose and viewpoint neutrality). These various standards are to some extent at odds with one another, and none of them provides a clear path forward for deciding future cases in other contexts.

But the situation is not unsalvageable. To say that the outcomes of the Supreme Court's compelled subsidization cases have been driven more by individual justices' legal and political intuitions about the facts before them than by a principled account of the First Amendment interests at stake is not to say that those cases were decided wrongly. It is the genius of the common law that judges can get it right before they know why. In this part, I attempt to abduce a different and more principled account of the First Amendment right against compelled subsidization. My thesis is that most, though not all, of the outcomes would be kept intact and provided a secure foundation were the Supreme Court to hold that the distinctive First Amendment interest at stake is not that of individual dissenters, but the potential harm to public political discourse.

\section{A. Old Holdings in New Theory}

It is hardly revolutionary to claim that the First Amendment's free speech clause is meant to protect not only individual speakers, but also the "marketplace of ideas." The thesis has a long pedigree and continues to play a role in discussions of the First Amendment, including the debates over the regulation of hate speech, pornography, broadcasting, and, as will be discussed in Part IV, campaign finance regulation. ${ }^{146}$ I will label such approaches "forum theories," because they consider one of the essential purposes of the Free Speech Clause to be the protection of expressive forums. Forum theories stand opposed to what I will call "liberty theories," which treat the protection of the individual's freedom of expression as the essential purpose of the First Amendment.

Forum theories are most often emphasized where individual liberties are perceived to threaten the free exchange of ideas or democratic processes. Campaign finance regulation is a paradigm case: the freedom

146 See, e.g., JOHN ELY, DEMOCRACY AND DISTRUST (1980); OWEN FISS, THE IRONY OF FREE

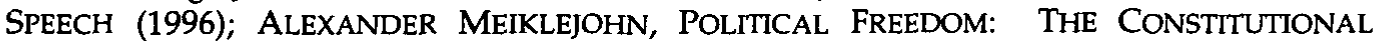
POWERS OF THE PEOPLE (1960); Owen M. Fiss, Free Speech and Social Structure, 71 IOWA L. REv. 1405 (1986). For criticism of the idea, see Robert Post, Meiklejohn's Mistake: Individual Autonomy and the Reform of Public Discourse, 64 U. COLO. L. REV. 1109 (1993). 
of wealthy individuals to wade into electoral discourse, it is claimed, distorts the electoral process. To protect the forum, we must restrict the liberty of individual contributors. ${ }^{147}$

This fact - that one most often sees an appeal to a forum principle where it is in opposition to the liberty principle - can give rise to the illusion that the principles stand in a necessary tension with one another. They do not, and not only because, as the forum theorist will tell you, individual freedom of expression is essential to a properly functioning marketplace of ideas. The principles are not coextensive in their consequences and there can be no tension where those consequences do not overlap. ${ }^{148}$ Part II showed that the doctrine of compelled subsidization cannot be explained by the liberty theory's emphasis on harm to individual dissenters. The suggestion now is that a forum theory can fill that gap.

One finds scattered references to this idea in the Supreme Court's compelled subsidization opinions. As early as 1961, Justice Black argued that the political expenditure of mandatory union dues "injects federal compulsion into the political and ideological processes, a result which I have supposed everyone would agree the First Amendment was particularly intended to prevent..1499 In his dissent from the Court's most recent compelled subsidization decision, Justice Breyer addresses the thought (though Kennedy's majority opinion did not mention it) with the observation that the compelled subsidization of commercial speech does not threaten any "special democratic need to protect the channels of public debate, i.e., the communicative process." ${ }^{\prime 150}$ Nor has the idea been lost on commentators. In a 1983 critical analysis of Abood, Norman Cantor argued that "[t]he critical constitutional interest at stake [in

147 Not that this is the only reason to regulate campaign financing.

148 For a similar idea, see Stern, supra note 114.

149 Int'l Ass'n of Machinists v. Street, 367 U.S. 740, 789 (1961) (Black, J., dissenting); see also id. at 788 ("Probably no one would suggest that Congress could, without violating [the First] Amendment, pass a law taxing workers, or any persons for that matter (even lawyers), to create a fund to be used in helping certain political parties or groups favored by the Government to elect their candidates or promote their controversial causes.").

Justice Harlan responded to this point in his concurrence to Lathrop, a case decided the same day, with the argument that there was a "clear distinction in the wording of the First Amendment between the protections of speech and religion, only the latter providing a protection against 'establishment,"' and that even if political establishment were a problem, government support of unions or bar associations "does not provide a fixed, predictable conduit for government encouragement of particular views." Lathrop v. Donohue, 367 U.S. 820, 852-53 (Harlan, J., concurring).

150 United States v. United Foods, Inc., 533 U.S. 405, 426 (2001) (citing Robert Post, The Constitutional Status of Commercial Speech, 48 UCLA L. REV. 1, 14-15 (2000)). 
compelled subsidization] is governmental establishment of particular political causes."151 But these have remained voices in the wilderness, as most justices and many commentators still hold fast to the idea that the harm is to individual dissenters. ${ }^{152}$ It is thus worth working through the details of the alternative approach.

Most, if not all, of the law of compelled subsidization follows from the least controversial sort of forum principle, which I will call the "political forum theory." From Meiklejohn on, proponents have focused the role of the First Amendment in the protection and fostering of political forums, as distinguished from scientific, artistic, commercial, or other speech platforms. The institutions in which political discourse takes place, it is argued, deserve special protection because "[a] free marketplace of ideas is essential to the proper functioning of a democratic system." 153 The First Amendment, on this reading, "protects the freedom of those activities of thought and communication by which we govern." ${ }^{\prime 154}$

From the general principle that a central function of the First Amendment is the protection of political forums we can extract any number of corollaries, some more controversial than others. The relevant one for our purposes is what Robert Kamenshine has called the First Amendment's "implied political establishment clause." ${ }^{\text {"155 }}$ This is the principle that the state has no business participating in public debate on contentious political issues (which is not to say that the state may not legitimately speak in other forums or on other topics). ${ }^{156}$ The idea is exemplified by the recent outcry over the Department of Health and Human Services ("HHS") production of videos that were distributed to

151 Cantor, supra note 23, at 7; see also Jacobs, supra note 23, at 171-76.

152 See especially Wasserman, supra note 23, at 191 ("The prohibition on government-compelled expression or support of private expression protects these interests in personhood and individual liberty by prohibiting government interference with individual thought, conscience, or belief through a requirement that one adopt, present, or support any message or idea that she does not wish to adopt, present, or support." (emphasis added)); see also Greene, supra note 23, at 466-67.

153 Robert D. Kamenshine, The First Amendment's Implied Political Establishment Clause, 67 CAL. L. REV. 1104, 1105 (1979). Kamenshine expressly limits his "political establishment" principle (see infra) to political speech. Id. at 1113 ("The principal interest that the first amendment protects is freedom of political expression necessary to the proper functioning of a democratic system. In view of this, courts should deny a first amendment challenge to nonpolitical speech by the government."); $c f$. Robert C. Post, Subsidized Speech, 106 YALE L.J. 151, 186-87 (1996).

154 Alexander Meiklejohn, The First Amendment Is Absolute, 1961 SUP. CT. REV. 245, 255.

155 Kamenshine, supra note 153 passim.

156 Participation in a marketplace is different from the regulation of a marketplace. On the version advocated here, the political establishment principle applies only to the former. 
local television news departments for rebroadcast without identifying HHS as their source and which portrayed a new Medicare drug law as a boon to the elderly. ${ }^{157}$ While the agency had an obligation to inform the public of the new rules, its job was not to promote the changes or the elected officials responsible for them. The intuitive idea that such "political establishment" is contrary to First Amendment principles can be filled out with two separate arguments.

First, public political discourse functions correctly when the mix of voices reflects the varying potencies of different viewpoints within the populace as a whole. The space that a given viewpoint occupies in the political marketplace of ideas should be a function of its adherents' numbers and the strength of their convictions. Government restrictions on speech cause distortions because they act like restrictive zoning ordinances, preventing certain views or interests from garnering the real estate they deserve. But as any developer will tell you, the shape of a city is driven just as much by government subsidies - tax breaks, bond issues, etc. The government also distorts public political discourse when it subsidizes (or forces others to subsidize) one viewpoint or interest at the expense of others. Because the First Amendment provides special protections to political forums, it prohibits such state interference with them.

The second argument involves a version of the "who will watch the watchmen" problem and applies particularly to debate on the policy and political issues on which elections turn - the issues that make up the platforms of candidates and political parties. Elected officials are interested parties in public discussion of these matters. Consequently, there is a danger that when these officials (or those beholden to them) put the government's muscle behind one side or another, it is not simply to express their views, but to use their power to perpetuate their positions in government. Because it does not employ the normative ideal of a proper mix of voices, this argument is less ambitious than the first. Instead, it emphasizes a special danger of government participation in political discourse. The problem here is not distortion, but conflict of interest and manipulation. ${ }^{158}$ As Kamenshine puts it, "[I]f

157 See Robert Pear, Ruling Says White House's Medicare Videos Were Illegal, N.Y. TiMES, May 20, 2004, at A24; Robert Pear, U.S. Videos, for TV News, Come Under Scrutiny, N.Y. TIMES, Mar. 15, 2004, at A1.

${ }_{158}$ The attentive reader will have noticed that this second argument involves a sort of anti-indoctrination principle. But unlike the risk of indoctrination through compelled speech (recall the discussion of Barnette above), the target indoctrinee is the public at large, not the individual subjects of a state compulsion. 
a government can manipulate [the] marketplace, it can ultimately subvert the processes by which the people hold it accountable. ${ }^{\prime 159}$

The most obvious tool for political establishment is government speech - where the state uses tax dollars to speak or to pay for the speech of others. ${ }^{160}$ But the compelled subsidization of private speech can likewise be a mechanism for political establishment. ${ }^{161}$ When the government requires some individuals to pay for the political or ideological speech of others, and when the recipients of the funds have an identifiable and controversial political agenda, then the government is essentially putting its muscle behind one interest or point of view at the expense of others and is engaging in a form of political establishment. This suggests the following standard for compelled subsidization cases: The compelled subsidization of the speech of others violates the First Amendment only when the funds collected are used to promote the message of an identifiable. viewpoint or interest in debate on a controversial political issue. $^{162}$ This relatively simple formulation gives rise to a number of

159 Kamenshine, supra note 153, at 1105 (footnote omitted); accord MARK G. YUDOF, WHEN GOVERNMENT SPEAKS: POLITICS, LAW, AND GOVERNMENT EXPRESSION IN AMERICA 15 (1983) (arguing that we must guard against government participation in political discourse that might be used "to falsify consent" by creating "a majority will through uncontrolled indoctrination activities").

160 These implications have been explored extensively in YUDOF, supra note 159.

161 In fact, Kamenshine reads Abood as a political establishment case. Kamenshine, supra note 153, at 1107-09. While Kamenshine is right that Abood's outcome can be justified on political establishment principles, the Court's reasoning was based on very different principles. See Abood v. Detroit Bd. of Educ., 431 U.S. 209, 234-36 (1977).

The idea of a political establishment principle is one way to unpack Tribe's reference to "legitimate goals" the state may seek to achieve when it speaks, which may be threatened by compelled subsidization. See supra note 145.

162 Cantor also argues that the crucial harm that the compelled subsidization doctrine protects against is government meddling in the political marketplace. But he focuses on the compelled subsidization of speech by unions and other service organizations, and ends up with a test that is more specific and makes more factual assumptions than the above proposal. Cantor concludes that there are sufficient safeguards against political establishment if "the institution benefiting from forced payments in fact performs a useful service, ... the payors are among the class benefiting, or potentially benefiting from such services [and] any 'political' outlays by the institution are related to the basic object of the institution ... and these political outlays are not being exploited strictly for partisan ends." Cantor, supra note 23 , at 38.

Jacobs argues that the constitutional touchstone for both compelled subsidization and compelled speech, which she would group together under the title "compelled expression," should be whether "the government's purpose is to manipulate the speech market to adjust the relative weights of the voices in it." Jacobs, supra note 23, at 171; see also Jacobs, supra note 9, at 459-69. With respect to compelled subsidization, this is broadly consistent with the above proposal. But there are significant differences in the details. For one thing, Jacobs attempts to resuscitate the Lathrop factors as the appropriate test under this rationale. Jacobs, supra note 23 , at 173-75. Jacobs's rule would also seem to hold that 
complexities in its application, which are the topic of the next part. Before turning to them, however, I want to argue that the standard provides a coherent account of the outcomes of the Court's compelled subsidization decisions to date.

This proposed test has two separate prongs. The first asks whether the compelled payments fund political speech. If not, then there is no violation of the political establishment principle. If they do fund political speech, the court must ask, second, whether they are used to fund an identifiable viewpoint or interest. Only if compelled payments do not fund political speech or an identifiable viewpoint or interest does the program pass First Amendment scrutiny.

The first prong provides a straightforward per se rule: so long as funded speech is neither political nor ideological, there is no First Amendment violation. This result is not surprising, given that, for the moment, we are considering the implications of a political forum theory. But it is also consistent with most of the Supreme Court's holdings in its compelled subsidization cases. The Court has occasionally held that nonpolitical expenditures do give rise to First Amendment violation. Ellis v. Brotherhood of Railway Clerks, which applied a limiting interpretation of the Railway Labor Act ("RLA") that maps onto the First Amendment right against compelled subsidization, ${ }^{163}$ held that a union's

the government's entrance into any sort of expressive forum, political or not, is impermissible. Thus she treats government manipulation of commercial speech as just as suspect as manipulation of political speech. Id. at 176-80. Finally, Jacobs lumps compelled speech together with compelled subsidization and assumes that both should be governed by a single rule. She takes, for instance, the fact that there is no "message alteration" in compelled subsidization to be an argument that this cannot be among the First Amendment harms of compelled speech. Id. at 166. As the analysis in Part II has demonstrated, compelled speech does harm individuals' First Amendment interests in a way that compelled subsidization does not. There is no reason to look for a single rule to govern both sorts of cases.

Wasserman also suggests that public forums, which embody a sort of viewpointneutrality principle, be immune from the right against compelled subsidization. Wasserman, supra note 23, at 231-36. But his argument for this approach relies on an account of the right against compelled subsidization that emphasizes the harm to individual dissenters and a notion that the forum mitigates this harm. "No speech is, in fact, funded with any fees charged and collected by the government in maintaining a public forum. Only the forum is funded; that is, only the physical place and the services associated with that place or only the pool of money." Id. at 231; see also id. at 168 ("A forum, in and of itself, is not expressive. Whatever private speech ultimately occurs in and through that forum is irrelevant to the payer's claim."). This quasi-metaphysical argument is unsatisfactory. As far as the individual dissenter is concerned (and Wasserman bases his argument on the potential harm to the individual), it makes no difference that her money is filtered through an intermediary organization or institution. The dignitary harm comes from that fact that she is foreseeably forced to fund speech with which she disagrees.

${ }_{163}$ Ellis v. Bd. of Ry. Clerks, 466 U.S. 435, 445-48 (1984). In examining the union dues at 
general organizing efforts were not sufficiently germane to collective bargaining to be allowable under the RLA. ${ }^{164}$ And, of course, United Foods held that compelled payments for industry advertising violated the First Amendment if the advertising was not embedded in a larger regulatory program. ${ }^{165}$ But these are the only two outliers. In both Ellis and Lehnert, the Court held that most of the challenged nonpolitical union expenditures did not violate the First Amendment (in Ellis, conventions, social activities, and union publications; in Lehnert, collective bargaining activities of the parent union, a nonpolitical union publication, conventions, and preparations for a potentially illegal strike). ${ }^{166}$ And Wileman went so far as to suggest that only "political or ideological disagreement with the content of the message" could produce a "crisis of conscience" and therefore implicate the First Amendment. ${ }^{167}$ While the proposed test suggests that the United Foods majority erred, the Court's other constitutional holdings can be kept largely intact.

As for the second prong, it is a factual question whether a given organization or program can be expected to engage in speech that is identifiable with a specific political viewpoint or interest. Justice Black maintained in his 1961 Street dissent that a union's use of members' funds for political and legislative activities "injects federal compulsion

issue in that case, Ellis first applied a limiting interpretation of the RLA set forth in Street, 367 U.S. 740 (1961), and then applied the Abood standard to the surviving expenditures. It is commonly recognized that Street's interpretation of the RLA is at best strained and informed less by the text of the statute than a concern to avoid the constitutional issue. See Int'l Ass'n of Machinists v. Street, 367 U.S. 740, 784-86 (1961) (Black, J., dissenting); id. at 799-803 (Frankfurter, J., dissenting); Abood, 431 U.S. at 232; Lehnert v. Ferris Faculty Ass'n, 500 U.S. 507, 555 (1991) (Scalia, J., concurring in part and dissenting in part); Air Line Pilots Ass'n v. Miller, 523 U.S. 866, 873 (1998). It is also commonly recognized that the Street interpretation of the RLA places that act precisely within the limits that later cases would establish for the First Amendment right against compelled subsidization. See Lehnert, 500 U.S. at 516 ("Although [it is a case] of statutory construction, Street [is] instructive in delineating the bounds of the First Amendment in this area as well."); id. at 555 (Scalia, J., concurring in part and dissenting in part) ("Street [was a statutory case], but there is good reason to treat [it] as merely reflecting the constitutional rule suggested in Hanson and later confirmed in Abood."). But see Communications Workers of Am. v. Beck, 487 U.S. 735, 76162 (1988) (applying Street interpretation of RLA to similar provision in National Labor Relations Act, despite fact that latter did not involve state action so as to raise First Amendment issue).

164466 U.S. at 451-53. Ellis also held that litigation not related to the bargaining unit in question was not allowable. Id. at 453 . The Court subsequently explained, however, that part of the problem was the "political and expressive nature of litigation." Lehnert, 500 U.S. at 528.

165 United States v. United Foods, 533 U.S. 405, 415 (2001).

166500 U.S. at 527-32.

${ }^{167}$ Glickman v. Wileman Bros. \& Elliott Inc., 521 U.S. 457, 472 (1997). 
into the political and ideological processes," an argument that assumes that unions take identifiable and controversial positions on political issues. ${ }^{168}$ Harlan replied in Lathrop that "the Integrated Bar does not provide a fixed, predictable conduit for governmental encouragement of particular views," a position he presumably also would have taken with respect to unions. ${ }^{169}$ The holdings of subsequent cases, read in light of the proposed principle, suggest that a majority of the Court eventually accepted Black's, and not Harlan's, assessment. Since recognizing the First Amendment right against compelled subsidization, the Court has consistently held that political expenditures by covered unions or integrated bars are unconstitutional. ${ }^{170}$ Whether this is empirically correct is, of course, debatable. ${ }^{171}$ But the outcomes of these cases are compatible with the recommended test.

Finally, the proposed standard correctly predicts the outcome in Southworth. While the university program at issue in Southworth involved the compelled subsidization of political speech, the Court found that the fact that funds were not earmarked for a single viewpoint or interest rendered it constitutional. ${ }^{172}$ Though the state university's student activity program fostered political speech, the university was not selectively funding such speech in a way that threatened the forum principle. Southworth's emphasis on viewpoint neutrality provides a map of where the Court should take the compelled subsidization doctrine.

The Court can begin to head in the right direction by reversing the Eleventh Circuit's holding in Veneman, overturning United Foods, and reaffirming the approach it took just four years earlier in Wileman. As Wileman recognized, compelled payments for industry-association advertising do no First Amendment harm to individual payers. Nor does governmental interference in this commercial forum violate the principles that coherently explain the Court's other compelled subsidization holdings. The beef advertising program at issue in Veneman may rub dissenting producers the wrong way. And such programs may well be problematic as a matter of public policy, for they

\footnotetext{
168 Street, 367 U.S. at 789 (Black, J., dissenting).

169 Lathrop, 367 U.S. at 853 (Harlan, J., concurring); Street, 367 U.S. at 797 (Frankfurter, J., dissenting, joined by Harlan, J.).

${ }^{170}$ See supra text accompanying note 83 .

171 For an argument that it is incorrect, see Cantor, supra note 23, at 31-35 (arguing that "[ $t$ rade unions and many professional associations are primarily service institutions rather than facades for a partisan political perspective").

17 Bd. of Regents of Univ. of Wis. Sys. v. Southworth, 529 U.S. 217, 233 (2000).
} 
often impose the costs of generic advertising disproportionately relative to the benefits conferred on individual industry members. But they do not violate the First Amendment. ${ }^{173}$

\section{B. Applying and Extending the Approach}

The above argument has something like the form of scientific induction. Beginning with the outcomes of the Supreme Court's compelled subsidization cases, I have proposed a standard that more coherently accounts for those holdings than does the Court's own reasoning. A First Amendment political establishment principle provides the best argument for most of the current limits on compelled subsidization. It provides a generally applicable, fairly bright line rule that applies to all compelled subsidization cases, as distinguished from the germaneness and the substantial-burden criteria the Court has applied in the past. That rule clarifies the relevance of the political or ideological content of expenditures. And the rule rejects United Foods' unexplained reliance on the existence vel non of non-expressive regulations. Finally, the approach rests on a sustainable account of the First Amendment interests at stake.

While the proposed standard is based on what is sometimes called a "collectivist" theory of the First Amendment, it does not threaten individual-liberty theories, which simply cannot account for the right against compelled subsidization. ${ }^{174}$ Compelled subsidization, unlike compelled speech, does no harm to individual dissenters' First Amendment interests. The political forum theory shows when and why compelled subsidization nevertheless poses a First Amendment problem.

This is not to say that the approach does not give rise to hard questions. One has already appeared: the factual question whether it is

${ }^{173}$ Such a holding would lie within the scope of the question the Court granted certiorari on: "Whether the Beef Promotion and Research Act of 1985 and the implementing Beef Promotion and Research Order violate the First Amendment insofar as they require cattle producers to pay assessments to fund generic advertising with which they disagree." Veneman, Pet. for Writ of Cert., 2004 WL 304352, at *I; Veneman v. Livestock Mktg. Ass'n, 124 S. Ct. 2389 (2004) [hereinafter Venemen, Pet. for Cert.]. The Court may choose to focus instead, however, on the issue of whether the generic advertising at issue in the case qualifies as government speech. See Livestock Marketing Ass'n v. USDA, 335 F.3d 711, 719-20 (8th Cir. 2003) (discussing whether program at issue in Veneman qualifies as government speech); Veneman, Pet. for Cert., at 14-24. Of course, it might also hold that United Foods effectively overruled Wileman, which would have the advantage of clarifying the law with respect to generic industry advertising, though it would hardly leave the doctrine as a whole better off.

174 See Post, supra note 146, at 1114-23; Morris Lipson, Note, Autonomy and Democracy, 104 YALE L.J. 2249, 2274 (1995). 
foreseeable that the recipient of compelled funds will use them to advance an identifiable political viewpoint or interest. There are at least three others: defining what counts as a "debate on a controversial political issue," whether we should expand the doctrine to prohibit the compelled subsidization of ideological speech, and the implications of even more robust forum theories.

If we stick with political forum theories, there is the definitional question: What counts as "debate on a controversial political issue"? Reading the proposed standard back into the cases, the Court's decisions provide some guidance. For instance, the union cases establish that prounion impact litigation is sufficiently political, while union conventions are not. But certainly there are undecided cases out there (e.g., IOLTAfunded constitutional litigation) and more work to be done.

One source for thinking about a generic definition is the Federal Communication Commission's ("FCC") now defunct fairness doctrine. ${ }^{175}$ In order to determine when a broadcaster was required to present alternative views of an issue discussed on the air, the FCC devised a twopart test: first, the issue must be controversial, as measured by "the degree of attention paid to [it] by government officials, community leaders, and the media"; second, it must be of public importance, for which the test is "not the extent of media or government attention, but rather a subjective evaluation of the impact that the issue is likely to have on the community at large., ${ }^{176}$ Another source for line-drawing is the Government Accounting Office's ("GAO") evolving interpretation of Congressional prohibitions on spending appropriated funds for unauthorized "publicity or propaganda."17 The GAO has interpreted such provisions to prohibit "the use of appropriated funds for materials that are self-aggrandizing, purely partisan in nature, or covert as to source," characteristics that can serve as additional indicators of particularly problematic expenditures in the context of compelled subsidization. ${ }^{178}$

175 See Kamenshine, supra note 153, at 1113-15.

176 The Handling of Public Issues Under the Fairness Doctrine and the Public Interest Standard of the Communications Act - Fairness Report, 48 F.C.C.2d 1, 12 (1974).

17 See, e.g., Labor Federal Security Appropriation Act of 1952, Pub. L. No. 134, ch. 373, $\S 702$, 65 Stat. 209, 223 (1951) ("No part of any appropriation contained in this Act shall be used for publicity or propaganda purposes not heretofore authorized by Congress.").

${ }_{178}$ In re Department of Health and Human Services, Centers for Medicare \& Medicaid Services - Video News Releases, File No. B-302710 (Gen. Accounting Office May 19, 2004), available at http://www.gao.gov/decisions/appro/302710.pdf; see also Letter from Anthony H. Gamboa, General Counsel, General Accounting Office, to Hon. Frank R. Lautenbert et al., 6-8, Mar. 10, 2004) (G.A.O. File No. B-302504), available at 
While the FCC and GAO decisions provide useful models, the definitional question is not simply a semantic one. Where one draws the line around the political should depend at least in part on why one thinks political establishment is problematic. Thus the who-will-watchthe-watchmen argument - according to which the problem with state participation in political discourse is that it can be used to "falsify consent ${ }^{\prime \prime 179}$ - suggests a relatively narrow definition. If the danger is incumbent protectionism, the relevant topics are just those likely to be at issue in the next election - the issues on which the candidates and parties differ. The distortion argument, on the other hand, which finds problematic the effect that state favoritism can have on the mix of voices, is compatible with a broader definition. On the broader reading, any number of controversial issues might count as "political," even though public opinion on them is not likely to affect election outcomes.

As the definition of the political gets broader, escaping the policy questions that drive elections, it shades into what might instead be called "ideological" speech, which I take to include both speech on uncontroversial policy matters (e.g., the validity of the Constitution) and on nonpolicy but highly charged value questions (e.g., abstinence vs. contraception). As far back as 1961, Justice Black complained that the political expenditure of mandatory union dues "injects federal compulsion into the political and ideological processes,"180 and the Court has since continued to invoke the two categories together. ${ }^{181}$ One explanation of the Court's regular inclusion of the ideological is its occasional mistaken adherence to a freedom-of-belief account, for ideological disagreement with the message funded is as likely to cause a crisis of conscience as is political disagreement. ${ }^{182}$ Having rejected that argument, it is worth asking whether there is another one for a right against funding ideological speech as well.

Both of the proposed arguments for a political establishment principle focus on the function of political forums in democratic decisionmaking. To the extent that an issue is neither a matter of current controversy nor

http://www.gao.gov/decisions/appro/302710.pdf. (discussing history of GAO's interpretation of publicity and propaganda prohibitions).

179 YUDOF, supra note 159, at 15.

180 Int'l Ass'n of Machinists v. Street, 367 U.S. 740, 789 (1961) (Black, J., dissenting) (emphasis added).

181 See, e.g., Glickman v. Wileman Bros. \& Elliot, Inc., 521 U.S. 457, 472 (1997); Keller v. State Bar of Cal., 496 U.S. 1,14 (1990); Abood v. Detroit Bd. of Educ., 431 U.S. 209, 235-36 (1977).

182 See Wileman, 521 U.S. at 472. 
directly related to public policy, it does not implicate such a principle. ${ }^{183}$ This is not to say that there are not good reasons for the government to keep its hands out of ideological forums. But expanding the compelled subsidization doctrine to include the compelled subsidization of nonpolitical, yet ideological speech involves more difficult line-drawing (what distinguishes legitimate topics of public health and welfare from nonlegitimate ideological matters?) and requires an argument beyond the narrow political establishment principle. ${ }^{184}$ Extending the doctrine in this direction might well be desirable, but would take some work.

Finally, it is worth considering the ways in which forum theories can cut the other way. Owen Fiss has championed a more far-reaching First Amendment forum principle, arguing that state promotion of socially orthodox viewpoints, such as "family values," at the expense of minority views may well violate the First Amendment. ${ }^{185}$ Fiss, therefore, can be counted among those who would expand the anti-establishment principle beyond the political to include at least ideological speech. But Fiss also argues that the First Amendment not only limits government expressive activities, but requires the government "to ensure the fullness and richness of public debate" by actively promoting minority viewpoints. ${ }^{186}$ Fiss's egalitarian forum principle might well authorize the compelled subsidization of political and ideological speech that expresses minority viewpoints.

This is not the place to examine all of the arguments for and against Fiss's theory. ${ }^{187}$ The point is only that once one shifts the focus away from the insult to individual dissenters to the impact of compelled subsidization on the general mix of expression, a host of new considerations emerge. While case outcomes have so far remained on the relatively uncontroversial ground of the "no political establishment"

183 Kamenshine, though he employs a who-will-watch-the-watchmen argument for his political establishment principle, nonetheless advocates a definition that encompasses what I would call "ideological" speech. Thus he would keep the public importance prong of the old fairness doctrine test and drop the controversy requirement. He concludes that while, for example, "[t]he capitalism-socialism debate . . . is hardly controversial . . . basic first amendment values should require that courts prohibit government expressions of the intrinsic superiority of a capitalist society." Kamenshine, supra note 153, at 1114. But it is doubtful whether this broad definition of the "political" is supported by Kamenshine's narrow argument for the political establishment principle.

${ }_{184}$ For a discussion of the line-drawing difficulties, see Lee $\mathrm{C}$. Bollinger, The Sedition of Free Speech, 81 MICH. L. REV. 867 (1983) (reviewing YUDOF, supra note 159).

185 FISS, IRONY, supra note 146 , at 37.

186 Id. at 41.

${ }^{187}$ For some cogent comments on the limits of Fiss's approach that are relevant in the context of compelled subsidization, see Post, supra note 153, at 187-92. 
principle, there may well be room for other claims.

\section{CONCLUSION: CAMPAIGN FINANCE REgUlation AGAIN}

This Article began by noting the way that recent campaign finance cases have raised not only the connection between money and speech, but also a version of the forum theory - the idea of a First Amendment interest in protecting the electoral process from the distorting effects of wealth. I want now to return to that topic and briefly survey what, if anything, the reformed account of the right against compelled subsidization has to say about campaign finance regulation.

We can begin with the relationship between money and speech. I have argued that when money is spent for speech, it does not, for First Amendment purposes, magically become equivalent to speech. This is not to say, however, that campaign contributions and other political donations do not have an expressive component. Buckley rightly saw that the act of contributing to a candidate or cause is often both intended and understood as a gesture of support. But the expressive content is limited, and it would be wrong to jump to the conclusion that money equals speech. The First Amendment requires empirical sensitivity to the nature of the expression, exactly where it is located, and when it is threatened. Buckley recognized that a cap on how much one may voluntarily contribute for the speech of another does limited harm to the undifferentiated expressive content of such contributions. ${ }^{188}$ The argument in Part II has shown that compelled payments do not even have that expressive content and even the limited protections of Buckley are no longer appropriate. ${ }^{189}$

What about the First Amendment interest in protecting political processes? While the political forum principle operates both in the compelled subsidization doctrine and in the area of campaign finance regulation, it does so in different ways. First, in the case of compelled

${ }_{188}$ By "expressive content" I mean the semantic content of the act of contributing itself. As Buckley additionally observed, campaign contributions also have an effect on the ability of the candidates who receive them to express themselves. Buckley v. Valeo, 424 U.S. 1, 2122 (1976). Buckley's discussion on this aspect of contributions rests on another corollary of the political forum theory: that candidates who must communicate with a large, dispersed electorate require a megaphone. Id. at 19 ("The electorate's increasing dependence on television, radio, and other mass media for news and information has made these expensive modes of communication indispensable instruments of effective political speech.").

189 This conclusion differs from Jacobs's claim that "the means of fee compulsion as opposed to expenditure restriction do not crucially distinguish the student activity fee and campaign finance issues." Jacobs, supra note 9, at 458. 
subsidization, the individual liberty theory does no work and the forum theory steps in to fill the gap. When it comes to campaign finance regulation, on the contrary, attempts to protect political discourse often conflict with the freedom of campaign contributors and independent advocates to spend their money, and even voice their opinions, as they wish. ${ }^{190}$ In this respect, campaign finance regulation requires a more robust forum principle, one that supports limitations on individual liberties that would otherwise trigger protections of the First Amendment.

Second, compelled subsidization is an area where the forum principle limits legislative action - the government may not force people to pay for the expression of an identifiable controversial political viewpoint or interest. In the case of campaign finance regulation, the forum principle does not limit what the state may do, but permits the legislature to enact laws that might otherwise contravene the First Amendment. Perhaps the strongest objection to the above account of the right against compelled subsidization is that courts are not equipped to police violations of the political establishment principle. In the case of campaign finance regulation, on the other hand, it is not the courts but the legislature that invokes the principle. There is therefore a place for judicial deference to legislative expertise in the campaign finance context.

There is no simple bridge from the way that the compelled subsidization doctrine acts to protect political discourse to a First Amendment forum principle that will support campaign finance regulation. But the compelled subsidization doctrine indicates one locale where the forum principle may already be at work in First Amendment jurisprudence. More judicial attention to how it operates in that area may at the very least make its application in the other less unnerving. Hopefully the Supreme Court will use Veneman to put courts on the road there.

190 Not all campaign finance regulation exhibits this to the same degree. See, e.g., BRUCE ACKERMAN \& IAN AYRES, VOTING WITH DOLLARS (2002). 
$* * *$

HeinOnline -- 38 U.C. Davis L. Rev. 1140 2004-2005 